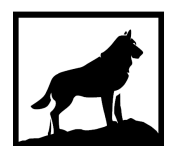

Michigan Technological

1 8 8 5 University
Michigan Technological University Digital Commons @ Michigan Tech

\title{
APPLICATION OF A DISTRIBUTED HYDROLOGIC MODEL FOR THE ANALYSIS OF LAND USE CHANGE IN KEDOUGOU, SENEGAL
}

Francisco Perez

Michigan Technological University, fperez@mtu.edu

Copyright 2019 Francisco Perez

Recommended Citation

Perez, Francisco, "APPLICATION OF A DISTRIBUTED HYDROLOGIC MODEL FOR THE ANALYSIS OF LAND USE CHANGE IN KEDOUGOU, SENEGAL", Open Access Master's Report, Michigan Technological University, 2019.

https://doi.org/10.37099/mtu.dc.etdr/901

Follow this and additional works at: https://digitalcommons.mtu.edu/etdr

Part of the Geology Commons, Hydrology Commons, and the Water Resource Management Commons 
APPLICATION OF A DISTRIBUTED HYDROLOGIC MODEL FOR THE ANALYSIS OF LAND USE CHANGE IN KEDOUGOU, SENEGAL

By

Francisco Perez Jr.

\begin{abstract}
A REPORT
Submitted in partial fulfillment of the requirements for the degree of MASTER OF SCIENCE

In Geology
\end{abstract}

MICHIGAN TECHNOLOGICAL UNIVERSITY

2019

(C) 2019 Francisco Perez Jr. 
This report has been approved in partial fulfillment of the requirements for the Degree of MASTER OF SCIENCE in Geology.

Department of Geological and Mining Engineering and Sciences

\author{
Report Advisor: John S. Gierke \\ Committee Member: David W. Watkins \\ Committee Member: Snehamoy Chatterjee \\ Department Chair: John S. Gierke
}




\section{Table of Contents}

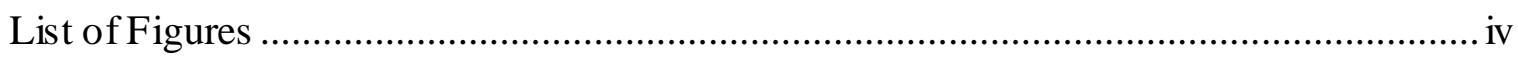

Acknowledgements .............................................................................................. vi

List of Abbre viations .............................................................................................. vii

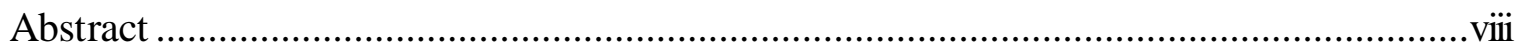

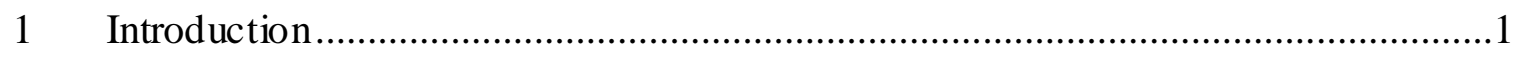

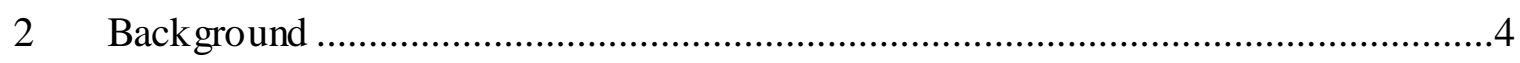

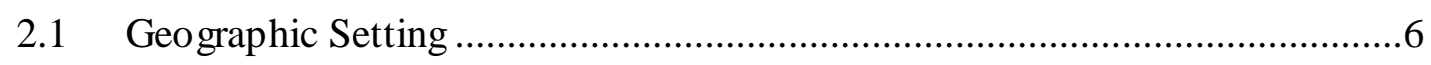

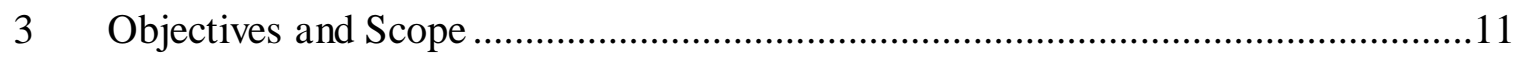

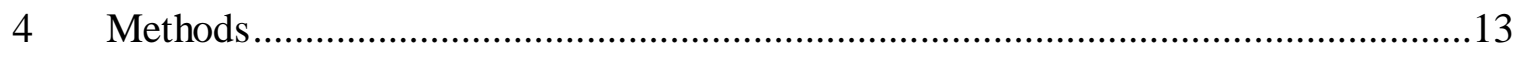

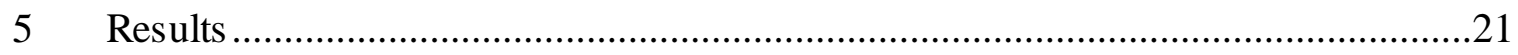

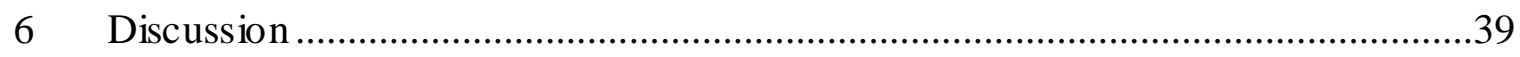

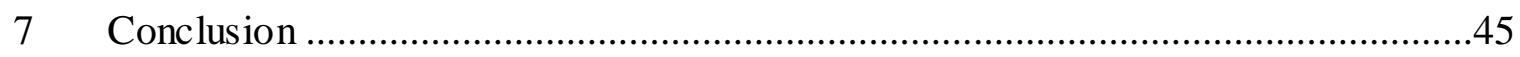

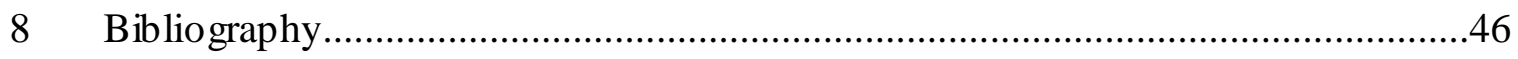

Appendix A. Processes and approximation techniques in GSSHA model.........................52

Appendix B. Overland Manning roughness coefficients (Downer and Ogden, 2006) ......53

Appendix C. Rawls and Brakensiek Soil Parameter Estimates (Downer and Ogden, 2006) 54

Appendix D. Calibrated Land Cover and Soil Parameters 


\section{List of Figures}

Figure 1. Map of Senegal in relation to Africa with the country's 14 region (inset). Adapted from Esri ArcGIS World Topo map and Wetterberg \& Gove (2011).......4

Figure 2. Kedougou population change between 1976 and 2019. Accessed from the Senegal National Agency of Statistics and Demographics (ANSD).

Figure 3. Kedougou is in the southeast of Senegal and is found near the conjunction of three countries- Senegal, Mali, and Guinea. The inset shows the urbanized capital of Kedougou and its proximity to the Gambia River. Adapted from Google Earth Pro (2019) (Map data: Google, CNES/Airbus, Landsat/Copernicus).

Figure 4. Map of KG-même showing hospitals and other important locations, major roads and streets, and residential areas. Some residential neighborhoods are within 200 m of the Gambia River. Accessed from OpenStreetMap, 2019.

Figure 5. Daily rainfall and Gambia River discharge from 1979-2003

Figure 6. IMERG hourly rainfall data.

Figure 7. Elevations found in the Gambia River watershed. KG-même is shown in the inset. Adapted from ASTER DEM satellite imagery found on the EarthExplorer database

Figure 8. Gambia River stream gradient

Figure 9. SOTER soil types in Kedougou. Adapted from ASTER DEM satellite imagery and SOTER data products.

Figure 10. Figure Land cover in the Gambia River watershed between 1992 and 2015. Data accessed from ESA CCI-LC viewer.

Figure 11. Land cover near KG-même between 1992 and 2015. Data accessed from ESA CCI-LC viewer.

Figure 12. IMERG hourly storm distribution. Precipitation amounts for 10 grid cells overlaying the entire watershed were calculated for every hour of the storm. Average amounts of rainfall per hour were calculated and distributed over time as a fraction of total rainfall.

Figure 13. Kedougou design storm hyetograph displaying rainfall distribution over time 
Figure 14. Hydrograph at Kedougou gauging station. The two peaks found in the observed data are not observed in the model simulation. Both simulations were relatively close to observed peak discharge.

Figure 15. Hydrograph of KG-même downstream outlet. After moving the outlet downstream, there was more variation in the hydrographs. Though, only the 1992 event reach observed peak discharge, each hydrograph maintained similar undulation.

Figure 16. Kedougou Inundation extent and depth (1992) ..........................................31

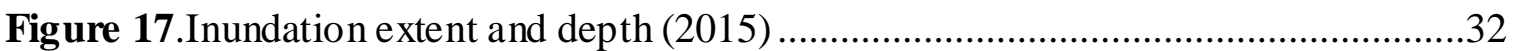

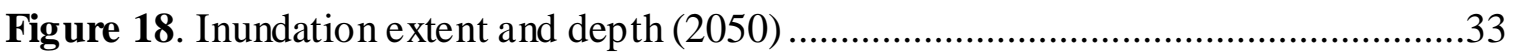

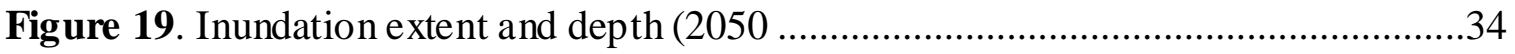

Figure 20. Gambia River near Kedougou- même. 08/06/18 (left), 08/18/18 (right) .........35

Figure 21. Gambia River near Kedougou-même. 08/06 ..............................................36

Figure 22. Gambia River near Kedougou-même. 08/06 ...............................................37

Figure 23. Gambia River near Kedougou-même. .............................................................38

Figure 24. Climate zones in West Africa. Each are differentiated by annual precipitation amounts, increasing further south. Accessed from the USGS website ..................40

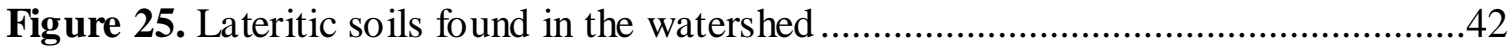




\section{Acknowledgements}

I would like to thank my advisor Dr. John Gierke, and my committee members, Dr. Snehamoy Chatterjee, and Dr. David Watkins for their assistance, patience, and availability.

Dr. Kari Henquinet who helped countless times before, during, and after the Peace Corps experience

Michigan Technological University and administration for their support

The United States Peace Corps, Peace Corps volunteer group, and my Senegalese host friends and family for their support and understanding

Moctar Sall, Moussa Cisse, and the other government scientists from the Direction de la Gestion et de la Planification des Ressources en Eau (DGPRE) of Senegal

Dr. Fred Ogden, colleagues, and researchers at the National Water Center Consortium of Universities for the Advancement of Hydrologic Science (CUAHSI)

Rudiger Escobar Wolf, Stephanie Tubman, Alex Wohlgemuth, Celine Carus, and the countless PCMIs and RPCVs who assisted me along the way

Brittany and Kelly from the Geology Department

Friends and family at Michigan Tech

Friends, family, and partner, Yabi, back home in New York City. 


\section{List of Abbreviations}

LULC- Land use and land cover

GSSHA- Gridded Surface/Subsurface Hydrologic Analysis

DEM- Digital Elevation Model

IMERG- Integrated Multi-satellite Retrievals for GPM

KG- Kedougou

KGM- Kedougou-même

Tamba- Tambacounda

PCMI- Peace Corps Masters International

TRMM- Tropical Rainfall Measuring Mission

DGPRE- Direction de la Gestion et de la Planification des Ressources en Eau (Ministry of Management and Planning of Water Resources) 


\begin{abstract}
West Africa has experienced extensive land use/land cover (LULC) change since the Sahel drought of the 1970s and 80s. Demographic changes, rapid urbanization, and other anthropogenic impacts on land cover in West Africa have potentially altered hydrological regimes. This work was undertaken while I served as a Peace Corps Volunteer in the Kedougou region of Senegal, an area that has experienced significant and rapid infrastructural improvements and urbanization since the early 2000s. The Gambia River flows near Kedougou, where flooding is an extensive problem, making access and livelihood practices difficult during the rainy season. Changes in climate and land use on hydrology have not been adequately assessed for this region, as well as many underdeveloped areas. A computational hydrological analysis is needed to understand recent and current conditions and forecast future impacts. The physically based and distributed Gridded Surface/Subsurface Hydrologic Analysis (GSSHA) model was employed to assess the effects of LULC change on inundation and local hydrology between 1992 and 2015. Urban area comprised $2.75 \mathrm{~km}^{2}$ of a $2,488-\mathrm{km}^{2}$ watershed in 2015, growing from nothing in 1992. Forest cover between 1992 and 2015 increased 6\%, whereas shrubland decreased by $4 \%$. The 2015 land cover results showed a $20 \%$ increase in peak discharge during high intensity precipitation events $(\geq 100 \mathrm{~m})$. However, during lower intensity storms, urbanization did not significantly impact local hydrology or streamflow. In fact, a reverse trend was observed, in which peak flow was $\sim 25 \mathrm{~m}^{3} / \mathrm{s}$ higher during the 1992 land cover scenario. Increased runoff may have resulted from the vegetation loss influenced by the drought from the 1980s. When compared to Sentinel-1 SAR imagery, GSSHA moderately overpredicted inundation extent.
\end{abstract}




\section{Introduction}

Understanding the hydrological impact of land use and land cover (LULC) change is indispensable to water resource management, urban planning, and flood analysis. "The need for accurate hydrologic analysis and modeling tools has been rapidly increasing because of the growing complexity of operational hydrologic and hydraulic problems associated with population growth, rapid urbanization and expansion of agricultural activities" (El Hassan, 2012). Anthropogenic activities such as deforestation, overgrazing, agricultural expansion, and urbanization can considerably affect the LULC and hydrologic characteristics of a basin (OECD, 1991). Although biophysical conditions such as local climate, geology, soil, and vegetation are the primary characteristics that influence land cover and local hydrology, human behavior can exacerbate LULC change. This can have both immediate and long-term impacts on local hydrology. In the short term, "land use changes may disrupt the hydrologic cycle through increasing the water yield and runoff" (Croke et al., 2004). Urbanization reduces the amount of permeable land, which leads to increased runoff, streamflow/peak discharge, and flooding during extreme precipitation events. "In the long-term, the reductions in evapotranspiration and water recycling arising from land use changes may initiate a feedback mechanism that results in reduced rainfall" (Savenije, 1995). As populations and urban areas develop, human interactions with the land will only grow increasingly more complex. Therefore, hydrologic models should be utilized and regularly updated to simulate and monitor the impacts of LULC change. Forecasts of impacts of LULC change on hydrology is one important effort to decrease social vulnerability and increase local resiliency.

Globally, many regions remain exceptionally vulnerable to flooding and drought hazards because they are underserved and lack resources for risk reduction and adaptation. West Africa, for example, has experienced extensive LULC change since the drought of the 1970 and 80s. However, in-depth studies for specific countries are lacking. According to Aduah et al. (2017), "in the rainforest regions of southern West Africa, there remains a lack of knowledge on the hydrological impacts of land use changes at the local scale, despite land use changes being significant over the past three decades" (FAO, 2010, Aduah et al., 2015). "Previous studies on hydrology in West Africa have been mainly undertaken in the semi-arid areas and the Sahel parts of the region that have vastly different vegetation and climate compared to the rainforest regions of the south" (Aduah et al., 2017). These studies acknowledged the various drivers of land use change and their associated effects (Welde et al., 2017, Koranteng et al., 2016, Tappan et al., 2004, Legesse et al., 2003). One study by Koranteng et al. (2016) used remote sensing products to predict future land use/land cover change up to the 2040 horizon. Others utilized different hydrologic models to analyze the effects of land use and land cover dynamics on multiple West African river basins (Welde et al., 2017, Legesse et al., 2003).

West Africa is comprised of 16 countries, as defined by the United Nations. Senegal serves a special interest to the author for it is where he served as an Urban Agriculture Volunteer in the U.S. Peace Corps in 2016 and 2017. According to the World Bank, urban populations in Senegal have considerably increased since 1960. Between 1960 and 2017, the urban population of Senegal increased from approximately 740,000 inhabitants to $7,200,000$. Almost half $(46 \%)$ of the total population currently live in urban areas, but this figure is projected to increase to $60 \%$ by 2030 (2016). Though urban migration is likely to increase, agriculture remains a prominent livelihood for a majority of the country.

Agricultural activities take place between May and October due to the rains brought by the West African monsoon wind system. While beneficial for crops, this can pose a 
threat to populations that reside near water bodies, in low elevations, or urban areas because of frequent flooding that occurs throughout the country. "Floods in Senegal have affected over 900,000 people and caused damage surpassing US $\$ 142$ million since 1980" (GFDRR, 2012). Many urban communities are at risk because of their location in coastal areas or proximity to one of the major river systems. High levels of rainfall variability, poor drainage infrastructure and shallow groundwater occurrence further increase the risk of inundation. Exposure to flooding has increased due to a history of rapid, unplanned, urban expansion into zones at risk (GFDRR, 2012).

In recent years, the Kedougou region in Senegal has experienced rapid urbanization. Between 2002 and 2014, the Kedougou urban population increased from 16,500 residents to 39,000 (ANSD, 2014). Approximately, 25\% of the regional Kedougou population lives in the urbanized capital, KG-même. Economic opportunities, instability in neighboring countries, and improved infrastructure are some factors that have influenced this growth. KG-même is in close proximity to the Gambia River and flooding is a major issue in the community during the rainy season. It limits travel and accessibility, destroys crops, and endangers livelihoods. Various groups (Bodian et al,, 2018, Traore et al., 2014) have completed studies analyzing the effects of climate change on the Gambia River. The authors estimated future stream flows under different climate change scenarios downstream of KG-même, but did not consider the effects of LULC change. As stated by Rogger et al. (2017), "Land use change has, potentially, a very strong effect on floods as humans have heavily modified natural landscapes. Large areas have been deforested or drained, thus either increasing or decreasing antecedent soil moisture and triggering erosion. Hillslopes were modified for agricultural production, thus changing flow paths, flow velocities, and water storage, and consequently flow connectivity and concentration times." During times of increased flow and large, convective rain events, the Gambia River is prone to higher flows and regular flooding. This study seeks to analyze how LULC change in KG-même has and will affect local hydrology, streamflow, and nearby inundation.

Several hydrologic models have been used to assess the effects of land use change; however, determining which model to utilize can be difficult and tedious. Dwarakish and Ganasri (2015) reviewed the applicability of various models to analyze the effects of LULC change on hydrological processes. The authors concluded that, "the physically based semidistributed and distributed hydrologic simulation models are more suitable for studying the effect of land use change, as land use pattern is heterogeneous in nature" (Dwarakish and Ganasri, 2015). Though multiple physically based, fully distributed models exist, the Gridded Surface/Subsurface Hydrologic Analysis (GSSHA) model was chosen for simulations. The fully distributed GSSHA model is, "intuitively more realistic compared to a lumped model in terms of land use change and has been successfully applied to smallmedium size watersheds with event-based and continuous configuration for predicting both stream flow" (Sith and Nadaoka, 2017). Additionally, the author participated in a sevenweek research program where he received extensive training from staff at the National Water Center using this model. The GSSHA model is utilized by NOAA in their National Water Model and continues to be employed for hydrological studies.

Kedougou is $\sim 740 \mathrm{~km}$ SE of the country capital, Dakar. Due to its location and population figures, it has historically been an overlooked and under resourced region. As of 2008, it was distinguished from Tambacounda and became its own, nationally recognized region. The distinction from Tambacounda granted the local government of Kedougou political and administrative privileges they previously lacked. Site-specific research funding might become available from this recognition to support collecting quality data and 
technical resources for Kedougou that are presently lacking. During his service, the author observed inundation throughout the region and realized the limitations this placed on residents, especially farmers. Through collaboration with the country's Department of Hydrology and Dept. of Water and Forests, the author obtained rainfall data, soil data, and digitized past hydrologic studies for Kedougou. The data was validated and supplemented by SIEREM, an online climatic database for West Africa, as well as satellite/radar imagery. The methods used to obtain, implement, and analyze these data can be found in section 4 .

The 300-m resolution GSSHA model simulated two flood events of varying precipitations. The $63 \mathrm{~mm}$ rainfall event was complemented by hourly discharge data that assisted when comparing results to observed data. The second simulation consisted of a 100 mm event that was compared to 20-m Synthetic Aperture Radar (SAR) flood imagery. Although data were limited by quality, this study aims to develop an accurate GSSHA model for an under resourced, but thriving community. Kedougou contains some of the most vulnerable, impoverished populations in Senegal. The author's hope is that this research improves the resiliency of the Kedougou population and can be employed for future land use scenarios in Kedougou and elsewhere. 


\section{Background}

An estimated 39 languages are spoken in Senegal (Hargreaves et al., 2019). The many cultures represented in the country are infused with a history of abundant migration and (re)settlement. Before French colonization, various African and Muslim empires ruled Senegal. Several ethnic groups, such as the Wolof, Fulani, and Soninke cohabitated Senegal under these empires. Due to its proximity to the Atlantic Ocean, many people have historically migrated here; however, this also influenced French colonizers to establish a prominent trans-Atlantic slave-trade post in the past.

Senegal is home to approximately 16 million people (ANSD, 2019). "It remains one of the most stable democracies in Africa and has a long history of participating in international peacekeeping and regional mediation" (CIA, 2019). Intra-continental migration continues to occur, but increased population growth and economic opportunities in Senegal have fueled urban migration.

The country is located on the western most tip of Africa (Fig. 1). It is comprised of 14 regions, each diverse in terms of population, culture, climate, and landscape. Of the 16 million inhabitants, $23 \%$ live in the capital Dakar, $13 \%$ in Thies, $11 \%$ in Diourbel, and $<10 \%$ in each of the other regions. Almost half $(46.7 \%)$ of the population live in urban areas. Average annual urban population growth rate is expected to remain above $3 \%$ until 2030 (Rouhana \& Ranarifidy, 2016).

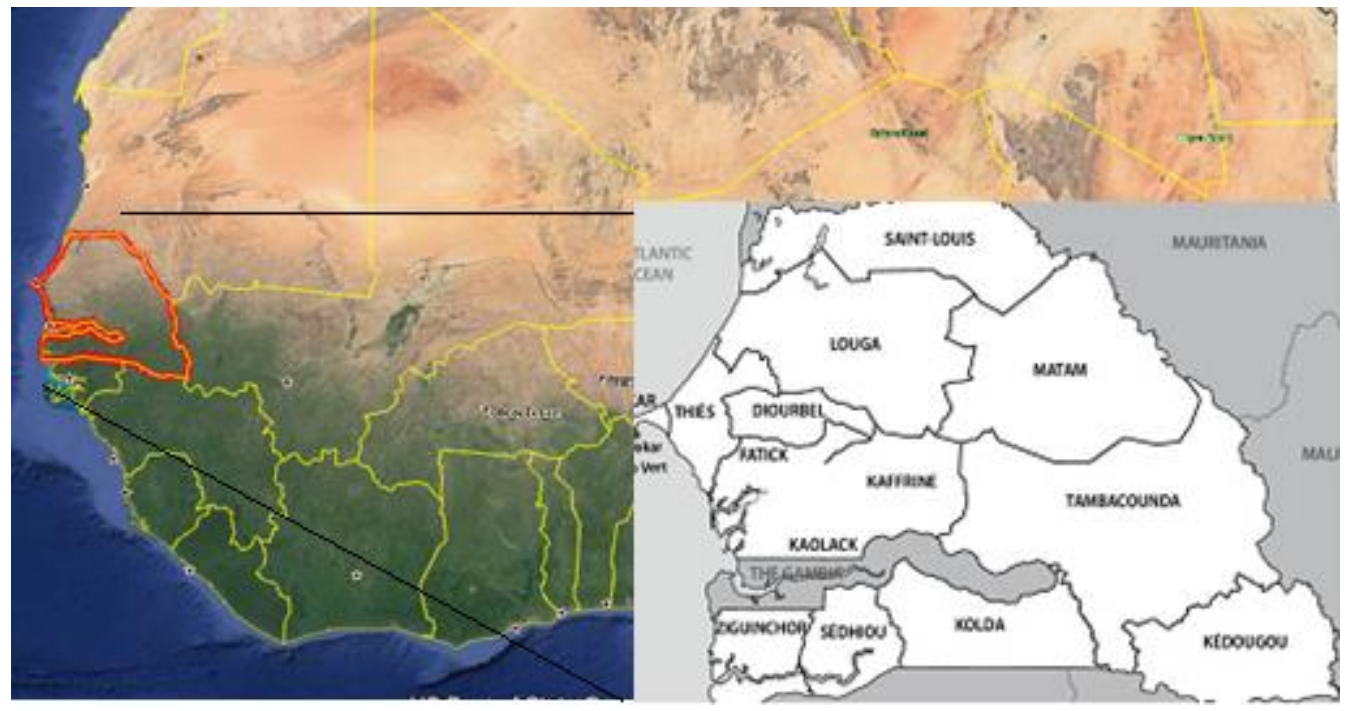

Figure 1. Map of Senegal in relation to Africa with the country's 14 regions (inset). Adapted from Google Earth Pro and Wetterberg \& Gove (2011) (Map data: Google, CNES/Airbus, Landsat/Copernicus).

As a United States Peace Corps volunteer, the author spent 2 years as an agricultural extension agent in Kedougou, Senegal. Much like states and counties in the U.S., Senegal is subdivided into regions and departments accordingly (Fig. 1). Regions possess local governments and have more political power and influence than departments. Prior to 2008, the entire region of Kedougou was considered a department of Tambacounda. However, it has now become its own region, allowing it political and administrative capabilities that it previously lacked. Kedougou is the fifth-largest region of Senegal with an area of 16,800 $\mathrm{km}^{2}$ but is also the least populated region. Although Kedougou is currently the least populous region, it has experienced a population increase of $190 \%$ from $\sim 63,000$ residents 
in 1976 to an estimated 184,275 in 2019 (Fig. 2). "The low population density in this area enabled movements of people from other populated zones for extensive agriculture and pastoralism purposes" (FAO, 2012). An estimated 60\% of the Senegalese population depends on agriculture for their livelihood and the Kedougou environment is suitable.

The 317 villages are scattered throughout Kedougou, but 2013 census data showed that urbanization has rapidly increased in recent years. Between 2002 and 2013, the percent of people residing in urban areas increased from $16 \%$ to $25 \%$ of the total Kedougou population (Beye et al., 2014). Urban migration has risen due to infrastructural improvements; during the author's service, the Senegalese government constructed a bridge and several roads that eased access between departments. Unstable political circumstances in bordering countries (The Gambia, Guinea, and Mali) have also increased migration to the area (Beye et al., 2014). Additionally, there has been increased industrial and artisanal gold mining in Kedougou since 2009. "The gold deposits in Kedougou have not only attracted international companies but also vast numbers of small-scale and artisanal miners who migrated from neighboring countries to Senegal" (Prause, 2017). "The mining and agriculture sectors have potential for economic benefits, but the exploitation of these resources might include environmental risks that add to the existing problems of bush fires, overgrazing, deforestation and soil erosion" (FAO, 2012).

Intensified environmental risks due to demographic change have the capacity to affect local hydrological systems. These risks, in addition to agricultural extension and urbanization, are major contributing factors to LULC change (OECD, 1991). Land use and land cover changes can have immediate and long-term impacts on local hydrology. In the short term, land use changes may disrupt the hydrological cycle through increasing the water yield and runoff (Croke et al., 2004). Increased runoff can expand and intensify inundation, thereby affecting agricultural livelihoods and personal property. In the long term, the reductions in evapotranspiration and water recycling arising from land use changes may initiate a feedback mechanism that results in reduced rainfall (Savenije, 1995). If the anthropogenic activities associated with urbanization continues to change the Kedougou landscape, hydrological studies must be performed to help decrease flood, climate change, and water resource vulnerability. 


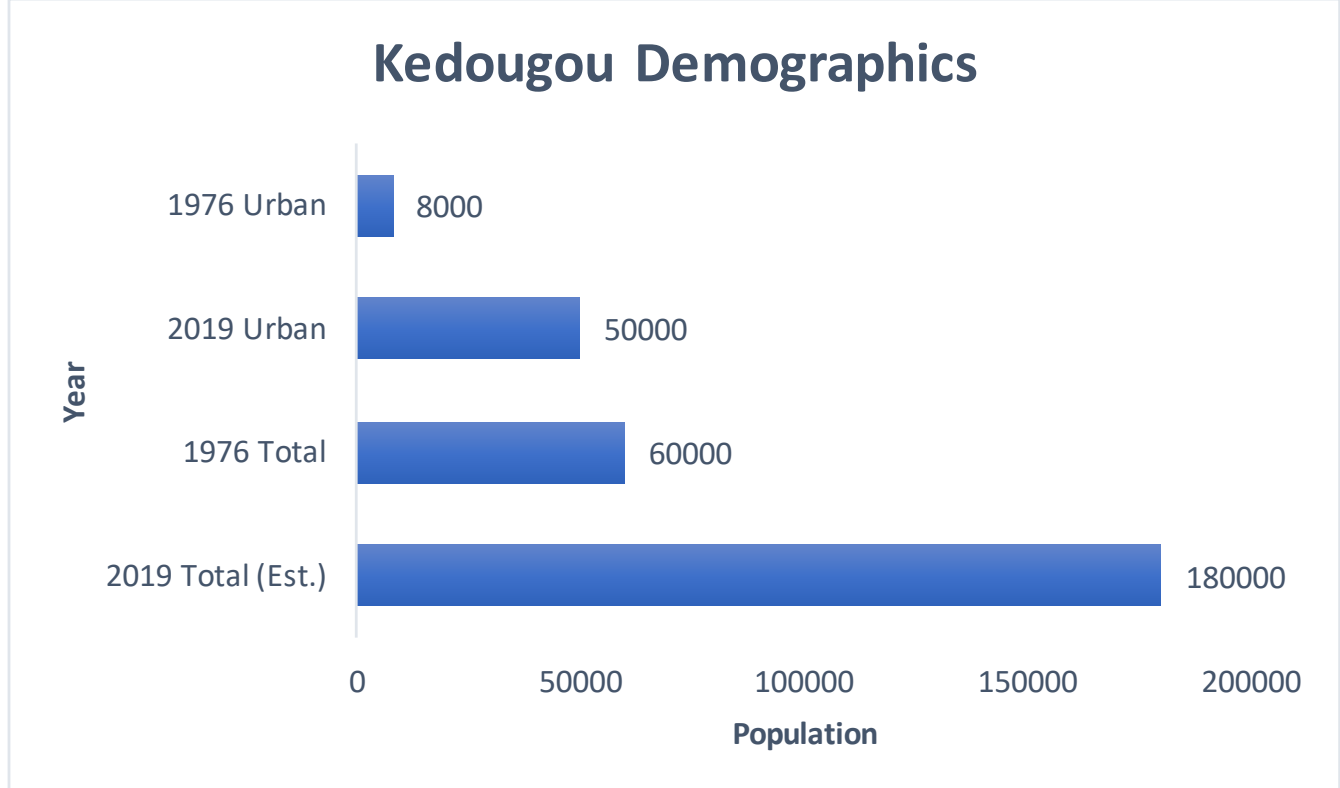

Figure 2. Kedougou population change between 1976 and 2019. Accessed from the Senegal National Agency of Statistics and Demographics (ANSD).

\subsection{Geographic Setting}

Kedougou is located in the southeast of Senegal at $12.5605^{\circ} \mathrm{N}, 12.1747^{\circ} \mathrm{W}$ (Fig 3). As evidenced by the gold that is found in Kedougou, this region contains markedly different geology, soils and climate than most of the country. While there are gold deposits located in a window of Paleoproterozoic rocks north and east of the capital, much of the geology surrounding KG-même consists of metasediments and biotite-bearing granitoids (Diop et al., 2006). The highest altitudes of the country are found here (about $500 \mathrm{~m}$ at the mountains of Kedougou) and exist as plateaus and hills that are the important sources of the hydrographic network (FAO, 2012). Kedougou contains, "very shallow, loamy, gravelly, and highly leached ferruginous soils over laterite and Precambrian parent material" (Tappan et al., 2004). Additionally, Kedougou boasts some of the highest precipitation amounts in the country, averaging 1,100 to 1,450 mm per year (Diop et al., 2015). This rainfall helps preserve the abundant natural forests and wildlife found in Niokolo-Kobo National Park, which borders Kedougou to the northwest, along with Mali (E) and Guinea (S). 


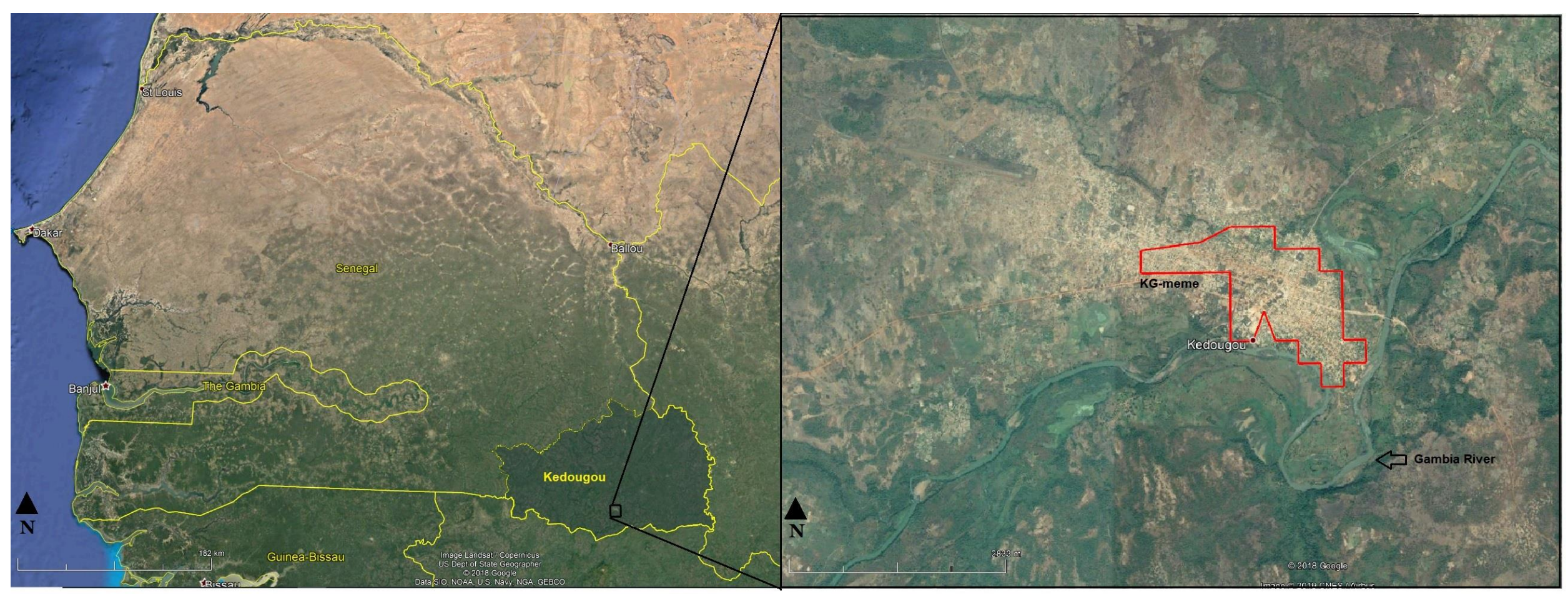

Figure 3. Kedougou is in the southeast of Senegal and is found near the conjunction of three countries- Senegal, Mali, and Guinea. The inset shows the urbanized capital of Kedougou and its proximity to the Gambia River. Adapted from Google Earth Pro (2019) (Map data: Google, CNES/Airbus, Landsat/Copernicus). 
Near the southern border of Kedougou, in Guinea, is the Fouta Djalon plateau. It is a mountainous region encompassing a 77,000- $\mathrm{km}^{2}$ area and is a series of stepped sandstone plateaus. The plateaus serve as watersheds for multiple West African rivers, including the Gambia River, Senegal River, and Niger River (Encyclopedia Britannica, 2012). The Fouta Djalon plateau is hydrologically vital to many West African communities. The Gambia River runs immediately adjacent to the capital, Kedougou-même (Fig. 4). The river originates in the Fouta-Djalon at an elevation of $\sim 1,200$ amsl. It travels $1,129 \mathrm{~km}$ through Kedougou and Tambacounda to its outlet in The Gambia. Between the Fouta Djalon plateau and Kedougou, the altitude decreases approximately 1,100 m. According to Diop et al. (2015), "this rather steep drop over $250 \mathrm{~km}$, combined with the abundant rainfall, explains, for a catchment area of approximately $10,465 \mathrm{~km}^{2}$, the flows recorded at the Kedougou station which can reach and even exceed 1,000 $\mathrm{m}^{3} / \mathrm{s}$." Most of the annual precipitation arrives during May-October, often peaking in August. Figure 5 shows daily rainfall and Gambia River discharge from 1979-2003. Quality data were limited to these dates. 


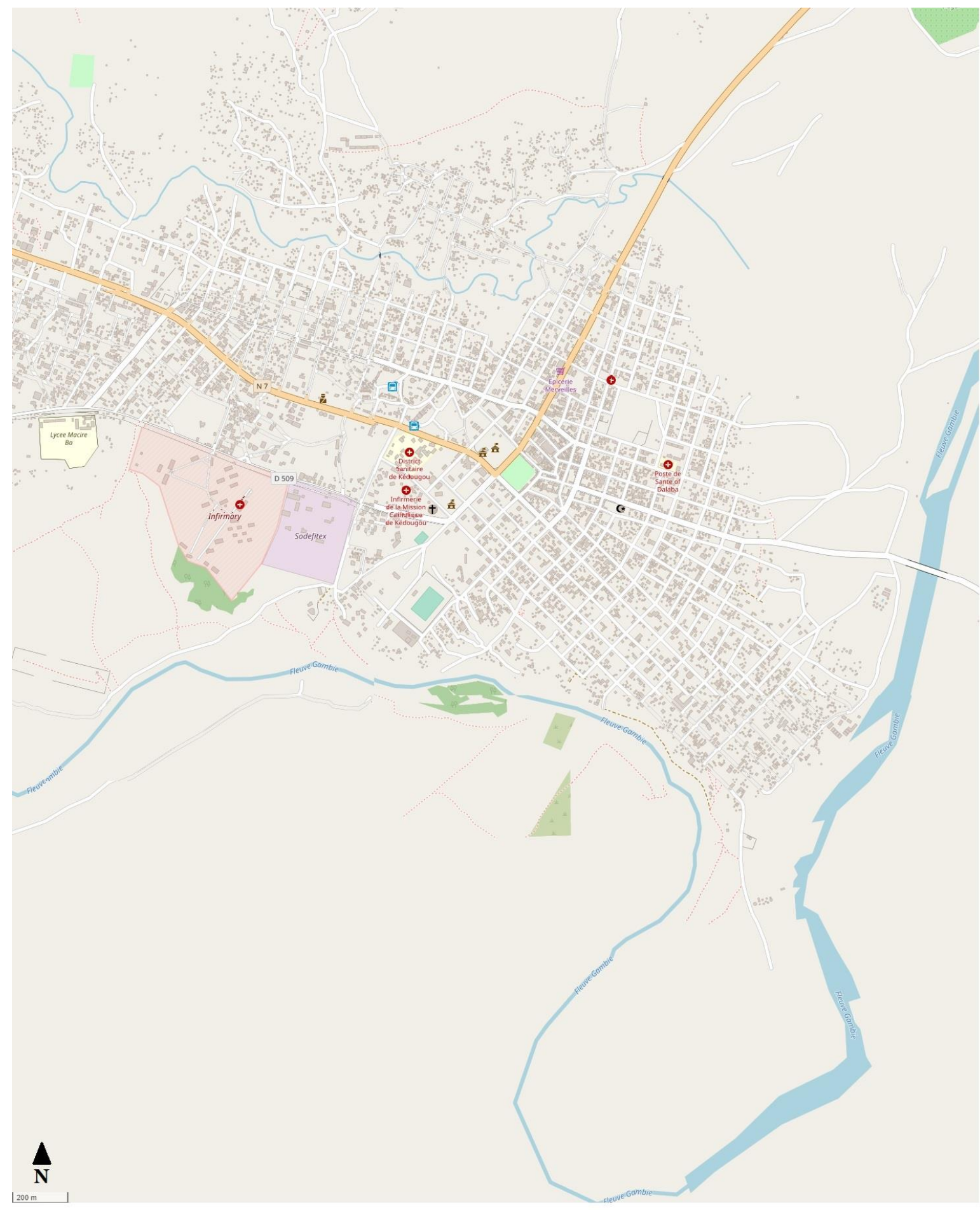

Figure 4. Map of KG-même showing hospitals and other important locations, major roads and streets, and residential areas. Some residential neighborhoods are within $200 \mathrm{~m}$ of the Gambia River. Accessed from OpenStreetMap, 2019. 


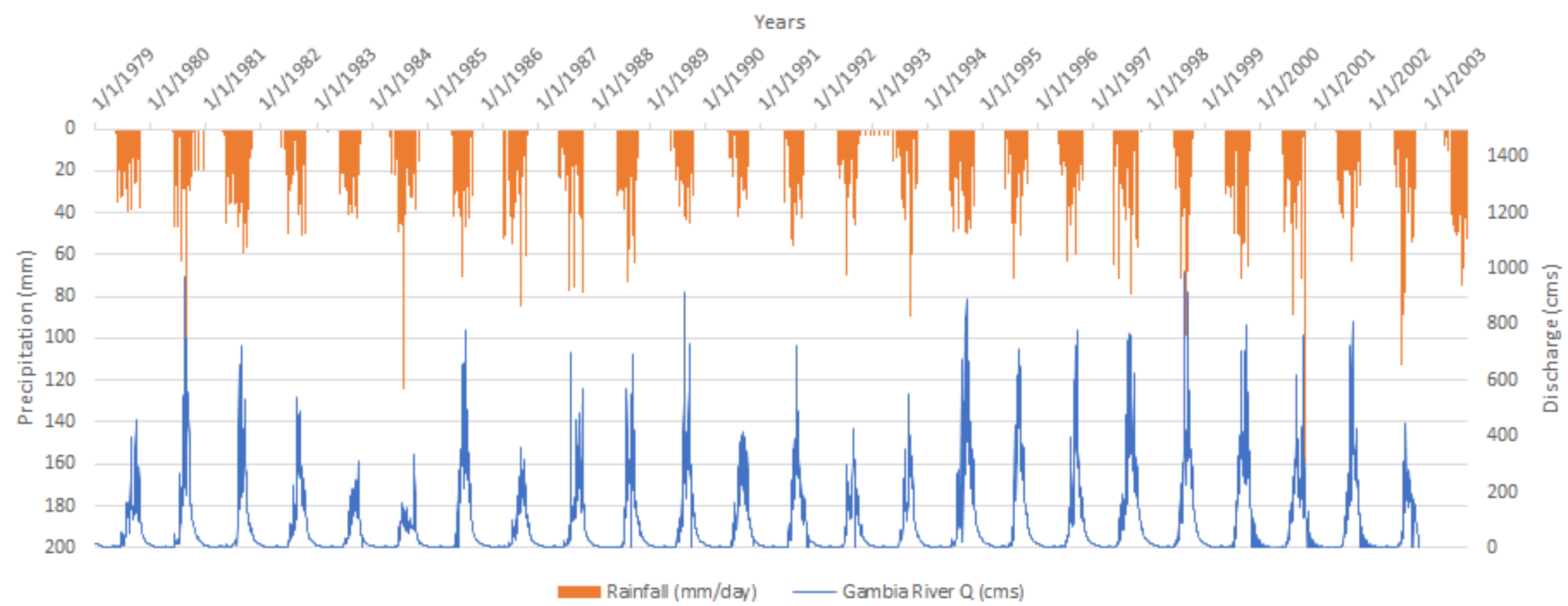

Figure 5. Daily rainfall and Gambia River discharge from 1979-2003 


\section{Objectives and Scope}

Based on Figures 2 and 4, it is apparent that KG-même has become more urbanized and densely populated since 1976. To assess how land cover in the watershed changed over time, satellite imagery between 1992 and 2015 were compared. The year 1992 was the earliest available global land cover dataset, so this was the land cover scenario used for calibration and pre-urbanization simulations. The 2015 land cover was the most recent image available and displayed how land cover transitioned.

Urbanization is associated with increased runoff due to impermeable surfaces. Increased runoff, combined with inadequate drainage systems, enhances flood risk for an already vulnerable community, as experienced by the author and his colleagues. The Kedougou urban community remains at risk because limited hydrogeological data in the Gambia River watershed has complicated and restricted hydrologic research and proactive solutions. There is one rain gauge at the airport and one broken stream gauge in the Gambia River near KG-même. Considering these factors, the research objectives are as follows:

1) Analyze land cover extent and class in the Gambia River watershed between 1992 and 2015.

2) Apply a GSSHA model to the Gambia River watershed to compare inundation extent and runoff impact due to LULC change

3) Test the model by comparing simulated results to a known event, as well as satellite imagery

4) Forecast future impacts of land use change on in the watershed at the 2050 horizon

Studies have shown that LULC change, especially urbanization, increases runoff, river discharge, and inundation depth and extent (Ligtenberg, 2017). In the future, climate change may exacerbate these effects as it can alter rainfall patterns, and increase storm frequency and intensity, thus increasing the potential for floods (Douglas et al., 2008). Rising temperatures are projected to cause more frequent and more intense extreme weather events detrimentally affecting communities that are already some of the most vulnerable and impoverished (Douglas et al., 2008).

Due to previous research experience at NOAA's National Water Center, the Gridded Surface/Subsurface Hydrologic Analysis (GSSHA) model was employed to simulate the hydrological effects of land use change. It is a physically based, distributed hydrologic model developed by the U.S Army Corps of Engineers. "It can simulate streamflow generated by various sources, such as snowmelt, runoff due to infiltration excess, or direction interactions between the stream and saturated groundwater" (Downer and Ogden, 2006). Additionally, the GUI and grid structure allow for multiple permutations of a storm event. In areas with limited data, this is beneficial because it eases manual calibration of individual parameters and saves time. Further information about the model is discussed in the Methods section. 
Land use dynamics were projected to the 2050 horizon by comparing the number of land use class grid cells that transitioned from forest to urban cover between 1992 and 2015. In GSSHA, grid cells maintain individual values that can be adjusted to correspond to a specific land cover. Between these 23 years, approximately 30 cells $\left(2.70 \mathrm{~km}^{2}\right)$ transitioned to urban land cover. To maintain the same rate of transition, 45 cells (4.05 $\mathrm{km}^{2}$ ) adjacent to KG-même were converted to urban area, representing the 35-year difference (1.5x) between 2015 and 2050 .

Kedougou is a highly under resourced and underrepresented region. It was just recently recognized as its own region in 2008 and allowed certain administrative/political privileges. As time progresses, the Senegalese government and other organizations should be able to provide Kedougou with more attention and resources than previous years. If present demographic trends continue, this region has the potential to become a major place of demographic and economic interest. The goal is that this model be utilized for water resource management and future flood mitigation strategies in Kedougoumême. Additionally, this model and methodology may be extended to other parts of Kedougou and Senegal. Kedougou is a place that should be served and represented more. 


\section{Methods}

Hydrological simulations occurred using the Gridded Surface/Subsurface Hydrologic Analysis model in the Watershed Modeling System (WMS). 300-m land cover data were obtained from the ESA website along with SOTER soil type characteristics and field/satellite-derived precipitation estimates. A $63 \mathrm{~mm}$ storm event from August 22, 2001 was simulated. Single storm events were modeled due to limited climactic data for long-term simulations. Additionally, previous modelling shows that the pattern of rare large floods is going to change much more than long-term average river flows in Africa (Douglas et al., 2008). GSSHA analyzed and calibrated the $63 \mathrm{~mm}$ rainfall event using the Gambia River's stream gauge. Post-calibration, the model simulated two rainfall events- first was the $63 \mathrm{~mm}$ event used for calibration and comparisons to observed data. Second, a $100 \mathrm{~mm}$ event was simulated based on flood extents found in SAR imagery. Simulated flood output and extent were compared to Synthetic Aperture Radar (SAR) from a 2016 flood event. SAR and GSSHA comparisons showed that SAR-detected flooding was more expansive than the $63 \mathrm{~mm}$ rainfall event, so a larger intensity $(100 \mathrm{~mm})$ storm was initialized.

\section{GSSHA}

"GSSHA is a physically based, distributed-parameter, structured grid, hydrologic model developed by the U.S Army Corps of Engineers (USACE)" (Downer and Ogden, 2006). THE USACE promotes GSSHA as a next generation model capable of simulating more complicated hydrologic/hydraulic situations such as land use change models, complex flows in a levee, or sediment transport within a watershed etc. (Downer et al. 2002). The model incorporates several important 1D and 2D hydrologic components, as outlined in Appendix A. Additionally, GSSHA has the capability to predict flooding from multiple sources, including excess rainfall, storm surge, stream overbank discharge, and reservoir expansion/back water (Downer and Ogden, 2006).

In this model, "the watershed is divided into cells that comprise a uniform finite difference grid" (Downer and Ogden, 2006). During an event, GSSHA spatially and temporally distributes rainfall over a watershed. The processes that occur before, during, and after a rainfall event are calculated for each grid cell and the responses from individual grid cells are integrated to produce the watershed response (Downer and Ogden, 2006). The GSSHA model is run in the Watershed Modeling System (WMS), which was developed at the Environmental Modeling Research Laboratory at Brigham Young University and is currently maintained by Aquaveo, LLC. This graphical user interface (GUI) makes the hydrologic model more accessible and user-friendly. Since GSSHA is a relatively new model, it continues to be updated by the USACE to improve the functionalities and efficiency of the model. There is an accessible GSSHA user manual online at "www.gsshawiki.com".

\section{Geospatial Data}


The GSSHA model requires spatial data in the form of Digital Elevation Models (DEMs), soil properties, land use coverage, and rainfall duration and intensity. The accuracy of GSSHA models is increased when utilizing hourly to sub-hourly precipitation data. In country, data access while was limited due to language barriers, transportation issues, and work schedules. The Direction de la Gestion et de la Planification des Ressources en Eau (DGPRE- Senegal Department of Hydrology) provided me with some research documents and rainfall records. These data were validated and supplemented by data obtained from other departments or sources. Various data products from different sources were integrated for model development.

\section{DEM Data}

Kedougou is located at $12.5605^{\circ} \mathrm{N}, 12.1747^{\circ} \mathrm{W}$, at the junction of the Mali and Guinea borders. The Gambia River originates in the Fouta Djallon mountain range of Guinea. A 30-m resolution ASTER DEM was retrieved from the EarthExplorer database. This DEM encompassed Kedougou and the Fouta Djallon plateau in Guinea. ArcMap 10.4 was used to merge the multiple images into a single DEM. Due to the relatively flat topography found in Kedougou, the Arc Hydro tool in ArcMap 10.4 was employed to artificially "burn" the Gambia River into the DEM. During the stream delineation process in GSSHA, slight elevation changes $(<5-6 \mathrm{~m})$ may not be detected accurately, thus affecting drainage patterns. "Stream burning is a common flow enforcement technique used to correct surface drainage patterns derived from digital elevation models" (DEM) (Lindsay, 2015). "The burn technique involves adjusting the elevations of grid cells that are coincident with the features of a vector hydrography layer" (Lindsay, 2015). After the burn process, Arc Hydro filled any remaining pits and sinks to ensure proper hydrologic simulation.

\section{Soil Type}

A detailed soil map of Senegal was obtained from the International Soil Reference and Information Centre (ISRIC) Soil and Terrain (SOTER) database. The SOTER database is composed of a map (in GIS polygon format) that delineates the SOTER map units accompanied by a database with terrain and soil data (ISRIC, 2019). Soil properties in the database consist of organic carbon, total nitrogen, $\mathrm{pH}$, cation exchange capacity, base saturation, aluminum saturation, calcium-carbonate and gypsum content, exchangeable sodium, electric conductivity, bulk density and the sand, silt and clay fractions.

\section{Land Use/Land Cover}

Datasets consisting of 300-m resolution, 21-class global land cover for every year between 1992 and 2015 were obtained from the CCI-LC viewer on the European Space Agency (ESA) website (ESA, 2014). "These datasets were compiled by several satellites, including MERIS, AVHRR, SPOT-VGT, and PROBA-V. The MERIS FR and RR archive from 2003 to 2012 was used to generate one unique baseline LC map" (ESA, 2014). "Independently from this baseline, LC changes were detected at $1 \mathrm{~km}$ based on the 
AVHRR time series between 1992 to 1999, SPOT-VGT time series between 1999 and 2013 and PROBA-V data for years 2013, 2014 and 2015” (ESA, 2014).

Changes detected at $1 \mathrm{~km}$ were mapped to a 300-m grid due to the resolution variability between sensors. The baseline LC map was then updated to produce 24 annual LC maps from 1992-2015. Since GSSHA cannot run continuously with dynamically changing land cover, maps from 1992 and 2015 were compared because they showed the largest LULC transitions. The land cover typology was defined using the Land Cover Classification System (LCCS) developed by the United Nations (UN) Food and Agriculture Organization (FAO). This LCCS was chosen so that it would also be compatible with the GLC2000, Glob Cover 2005 and 2009 products (ESA, 2014).

\section{Hydrometeorological Data}

Kedougou-même maintains one rain gauge at the nearby Kedougou airport. Daily rainfall data from 1918-2007 were obtained from the DGPRE and validated by SIEREM, Système d'Informations Environnementales sur les Ressources en Eau et leur Modélisation. SIEREM is an environmental information system for water resources in Africa, developed by HydroSciences, Montpellier, Vermont. It is considered the most important environmental information system on the African continent with 13,000 measuring stations, 33,000 time series, and over 117 million records, from 1837 to 2015. "As precipitation is highly variable in space and time, a dense network of rainfall stations is needed" (Chintalapudi et al., 2012). However, "the accuracy of precipitation data is much lower in developing countries" (Pan et al., 2010). Limited rain gauges and coarse temporal resolutions can result in hydrologic inaccuracies. The GSSHA User's Manual suggests avoiding precipitation data with a temporal resolution coarser than 1 hour (Downer \& Ogden, 2006).

Therefore, the temporal distribution of rainfall was determined by satellite imagery. The Integrated Multi-Satellite Retrievals for GPM (IMERG) data product was utilized to develop a design storm hyetograph. GSSHA can employ a hyetograph that models temporally varying, spatially uniform (single-gauge) rain events. "The IMERG data product intercalibrates, merges, and interpolates multiple satellite and microwave precipitation estimates, together with microwave-calibrated infrared (IR) satellite estimates, precipitation gauge analyses, and potentially other precipitation estimators at fine time and space scales for the Tropical Rainfall Measuring Mission (TRMM) and Global Precipitation Measurement (GPM) satellites over the entire globe" (NASA, 2019). This precipitation data is not only validated through several methods, but data is also available at a half-hour time step and $0.1^{\circ}$ grid resolution. IMERG data products have been available since March 2014.

According to Weather Underground, $\sim 50 \mathrm{~mm}$ of precipitation occurred on August 27 to 28, 2014 (Weather Underground, 2019). Hourly accumulated rainfall data were available for this storm event in NASA's Giovanni database. Hourly images of the storm event were retrieved and imported to ArcMap 10.4 (Fig. 6) The Info tool was used to determine precipitation values for each grid cell. Rainfall values were averaged over to 
time to develop a design storm hyetograph. The hyetograph distributes precipitation based on the ratio of rainfall per hour to accumulated rainfall.

After the hyetograph was developed, accumulated rainfall from a $63 \mathrm{~mm}$ storm event on August 22, 2001 was used for simulation. This date was chosen because little to no rain preceded or succeeded this event for three days. The lack of precipitation before and after would minimize hydrological inaccuracies. Additionally, quality hourly discharge data were available for this event.

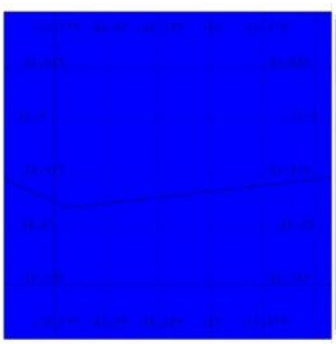

$04: 00$
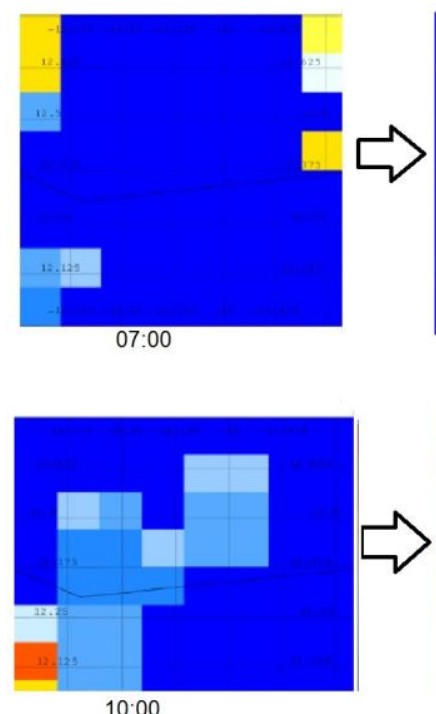

$10: 00$

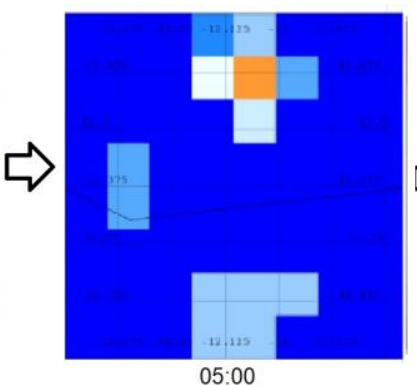

05:00

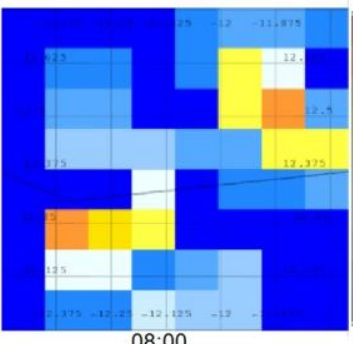

08:00

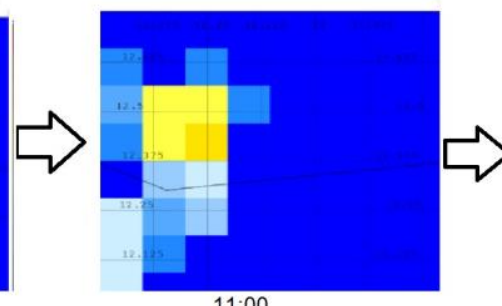

$11: 00$

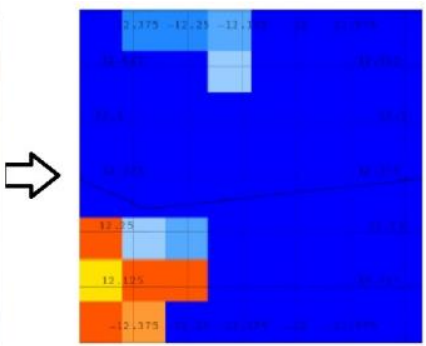

06:00
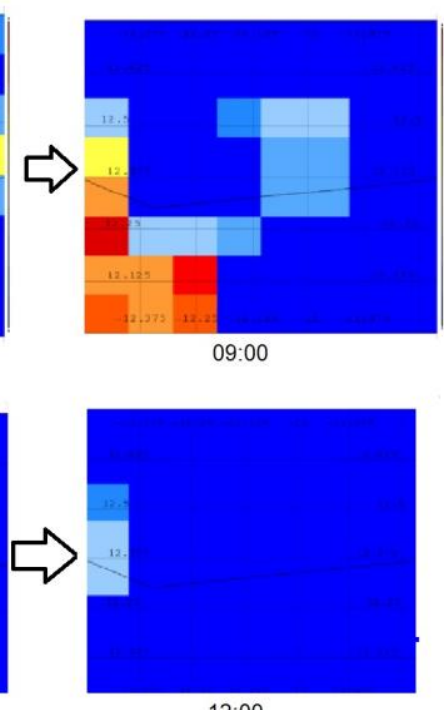

Figure 6. IMERG hourly rainfall data

\section{Gambia River discharge data}

Kedougou maintains several gauging stations on the Gambia River and some of its tributaries. The KG-même gauging station maintained daily discharge values from 1970-2003, before a flood washed out the station (Diop et al., 2015). Unfortunately, resources have not yet been allocated to fix this. The SIEREM database contained daily discharge data from 1970-2003. Data before the 1990s were explicitly recorded daily; however, after 1990, during intense precipitation events, discharge was recorded at a one to three-hour time step. This finer temporal resolution proved necessary for model calibration. 


\section{Document translation}

Senegal is a Francophone country and much of the research, data, and information I received were in French. Google Translate was used for translation to English.

\section{GSSHA Model Creation}

\section{Preprocessing}

Several preprocessing procedures occurred before GSSHA model initialization. First, the datum and projected coordinate system established were WGS 84 UTM Zone $28 \mathrm{~N}$. This projection encompassed both Kedougou and the Fouta Djallon plateau of Guinea. Next, the burned DEM was imported to WMS for flow direction and flow accumulation computations through the Topographic Parameterization Program (TOPAZ) included in WMS. Once TOPAZ calculated the stream network, an outlet was chosen to delineate the watershed.

Outlet placement is an important consideration during model development because GSSHA produces a river hydrograph at the location, enabling calibration. For calibration purposes, the Kedougou gauging station was chosen as the initial outlet point. However, when this watershed was delineated, it did not encompass the town of Kedougou. Once soil and land cover parameters were calibrated utilizing this outlet point, a new outlet, encompassing the town, was chosen $\sim 10-\mathrm{km}$ downstream. After watershed delineation, the GSSHA model was selected and initialized.

\section{Grid Size and Stream Smoothing}

After preprocessing, a 2D elevation grid of the DEM was created. Distributed models can have an extensive range of grid sizes; therefore, "the selection of an appropriate grid size requires consideration of both the available data and computational effort required" (Downer and Ogden, 2006). Smaller grids can increase model accuracy because they are less sensitive to sub-grid variability for Hortonian runoff (Ogden and Julien, 1993), but this may not equate to enhanced model performance. Computational demands are dependent on a myriad of factors that include grid size, watershed area and stream network density. "If the grid size of the model is halved, the memory required, and computational time increase by a factor of 4" (Downer and Ogden, 2006). A 300-m grid was chosen since it coincided with the spatial resolution of the land cover dataset. In addition, this grid size reduced computational demand and provided enough detail to display individual land cover types.

After grid generation, the stream network was adjusted and smoothed. The adjustment process ensured that the stream network was geographically accurate. The smoothing process involved redistribution of the vertices found in each stream and the adjustment of channel profiles to eliminate adverse slopes. Additionally, it ensured streambed elevations were lower than that of the adjacent land surface. This is critical in low gradient areas, such as Kedougou, because "streambed elevations should always be lower than adjacent surface elevations" (Downer and Ogden, 2006). Ideally, surveyed cross sections and riverbed profiles of the channel network would be used to smooth the streams; however, this data was not available for the study area. 
Channel cross-section attributes for the streams were incorporated after the smoothing process. True channel cross sections were unavailable. Shapefiles of the watershed and stream network were exported from GSSHA to ArcMap 10.4. On the stream network, new points were created every $2 \mathrm{~km}$ using the Editor tool. At each of these points, the Ruler tool in ArcMap estimated channel width. The Info tool and DEM were used in conjunction to determine the riverbed profile by measuring the elevation on the banks and middle of the river. The $2 \mathrm{~km}$ point shapefile was then imported to GSSHA and nodes matching these points were created along the stream network. Node creation allows partitioning the drainage network into individual segments with their own corresponding attributes.

\section{Land Cover and Soil Type}

The land cover and soil type GIS shapefiles were imported to GSSHA, clipped to the watershed boundary, and converted to coverage and index maps. Coverage maps assign spatially varying grid parameters by mapping the points, arcs, and polygons of a GIS coverage to an index map of unique land use, soil texture, or land use/soil texture IDs. Mapping tables that relate the parameter values of the IDs can then be developed. These tables attribute several different parameters for land use and soil type to each ID on an index map. Surface roughness (Manning's N) coefficients for each land cover were unavailable in this dataset. Prior to model calibration, several coefficient values from literature were tested in a manual quasi-sensitivity analysis (Appendix B).

The SOTER database accompanied the soil data. During previous studies, saturated hydraulic conductivity demonstrated high sensitivity and output variability for the GSSHA model. Hydraulic conductivity $(\mathrm{K})$ was determined with the Soil Water Characteristics tool in the USDA SPAW Hydrology and Water Budgeting program. This tool is used to simulate soil water tension, conductivity and water holding capability based on the soil texture, with adjustments to account for gravel content, compaction, salinity, and organic matter (USDA, 2019). The program is based on the soil-water retention curve, so it is important to remember they are estimations and may not reflect the true values at site. Saturated hydraulic conductivity, field capacity, wilting point, and residual saturation were obtained through the program (Appendix C). Unobtainable soil properties such as capillary head, porosity, and pore distribution index were assigned literature values based on soil texture.

\section{Precipitation}

The hyetograph developed from IMERG data earlier simulated a $63 \mathrm{~mm}$ (average depth) rainfall event that occurred on 08/22/2001. Minimal rainfall was experienced three days prior and after this event. Since the hyetograph assumes a single gauge in the watershed, the model spatially distributed rainfall uniformly over the entire watershed for a 10-hour period. 


\section{Output and Calibration}

The chosen output parameters to display were inundation extent and maximum flooding. Additional information about the watershed hydrology is also automatically generated. Before simulation, GSSHA employs a cleanup option that detects errors and ensures the model can run. Once verified, simulations occurred with the 1992 land cover until antecedent streamflow conditions were reached. GSSHA has the capability to save discharge and water surface elevation values in each grid cell along the stream network. Once discharge reached a steady state of $\sim 170$ to $190 \mathrm{~m}^{3} / \mathrm{s}$, the model was ready for calibration.

Calibrated parameters included Manning's $\mathrm{N}$ for land cover surface roughness and channel roughness, saturated hydraulic conductivity $(\mathrm{K})$, and initial soil moisture content. GSSHA offers a PEST-based calibration routine that determined values based on the 1992 land cover. Once calibration values were obtained from the Kedougou gauge outlet, they were saved as a text file and imported to another model in which the outlet point was $10-\mathrm{km}$ downstream. The parameters were extrapolated to 2015 and 2050 and the model was simulated for 1992, 2015, and 2050. Land cover parameters were manually adjusted for improving the hydrograph accuracy and calibrated a second time (Appendix D).

\section{Testing}

The results of the GSSHA analysis were compared to Synthetic Aperture Radar (SAR) imagery, specifically the Sentinel-1 satellite. "The Sentinel-1 mission comprises a constellation of two polar-orbiting satellites, operating day and night performing C-band synthetic aperture radar imaging, enabling them to acquire imagery regardless of the weather" (ESA, 2019). This mission has a 12-day repeat cycle, thereby enhancing difficulty in obtaining flood data. However, images for pre-flood $(08 / 06 / 16)$ and flood $(08 / 18 / 16)$ conditions were obtained through the Vertex data portal maintained by the Alaska Satellite Facility (ASF). These images were processed in the ESA Sentinel Application Platform (SNAP). Once imported, the satellite images were clipped to encompass the river and area near Kedougou. Processing procedures for the radar imagery included radiometric calibration, terrain correction, and speckle filtering. The flood imagery was imported to ArcGIS for comparison to the GSSHA flood grid output.

Once a model is executed in GSSHA, the flood grid output displays maximum flooding in each grid cell at any given time. The flood grid was exported as an ASCII grid file to ArcGIS. The raster calculator was implemented for both raster files. The SAR flood imagery was adjusted to differentiate land and water. The flood grid was changed so that floods with a minimum height of $1 \mathrm{~m}$ would be displayed. These raster datasets were then converted to shapefiles and combined into one file through the Conversion and Union tools.

When comparisons were complete, it was apparent the rainfall event that occurred on 08/18/16 was a larger event than the $63 \mathrm{~mm}$ event run in the initial GSSHA model. However, Kedougou rainfall data for the date of the SAR imagery were unavailable. Thus, another GSSHA model was run, all parameters the same, except for precipitation. 
The precipitation for this second event was $100 \mathrm{~mm}$. This was done to verify if the GSSHA flood output would coincide with the full extent of the radar-derived flood event. 


\section{Results}

The Gambia River generally flows north, until reaching KG-même where it turns NE. The watershed at the Kedougou outlet has an area of $2,488 \mathrm{~km}^{2}$. Approximately $72 \%$ of the watershed exists on the Guinean side of the border, identified by the steep drop in elevation. Figure 7 displays DEMs of the watershed and KG-même. Maximum elevation is found in the Fouta Djallon Plateau at $\sim 1,530 \mathrm{~m}$ amsl. Multiple elevations were found in KG-même, ranging from $\sim 100-140 \mathrm{~m}$ amsl. The elevation of the Gambia River drops 90 $\mathrm{m}$ over a $90 \mathrm{~km}$ distance. Figure 8 displays the stream gradient.

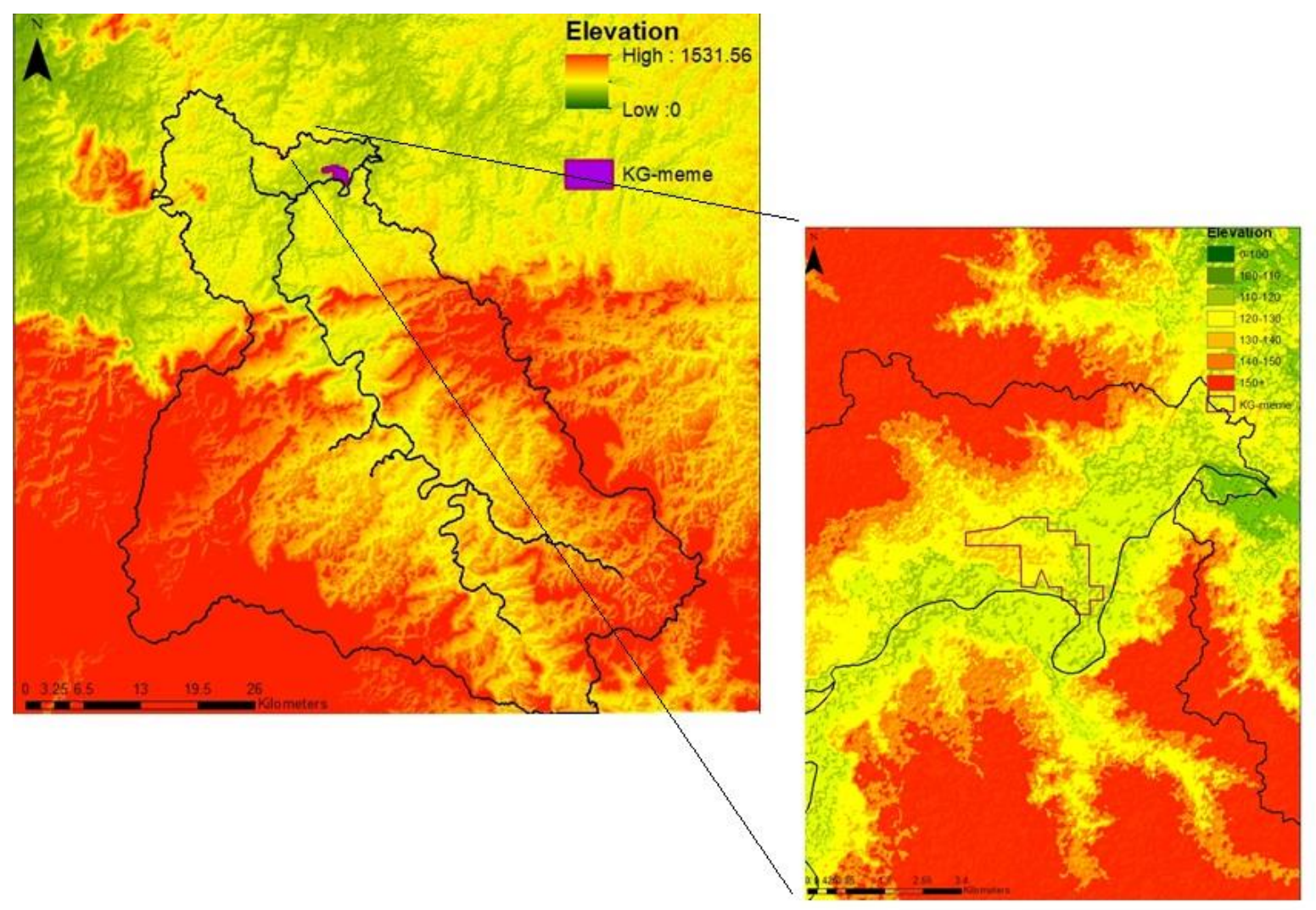

Figure 7. Elevations found in the Gambia River watershed. KG-même is shown in the inset. Adapted from ASTER DEM satellite imagery found on the EarthExplorer database 


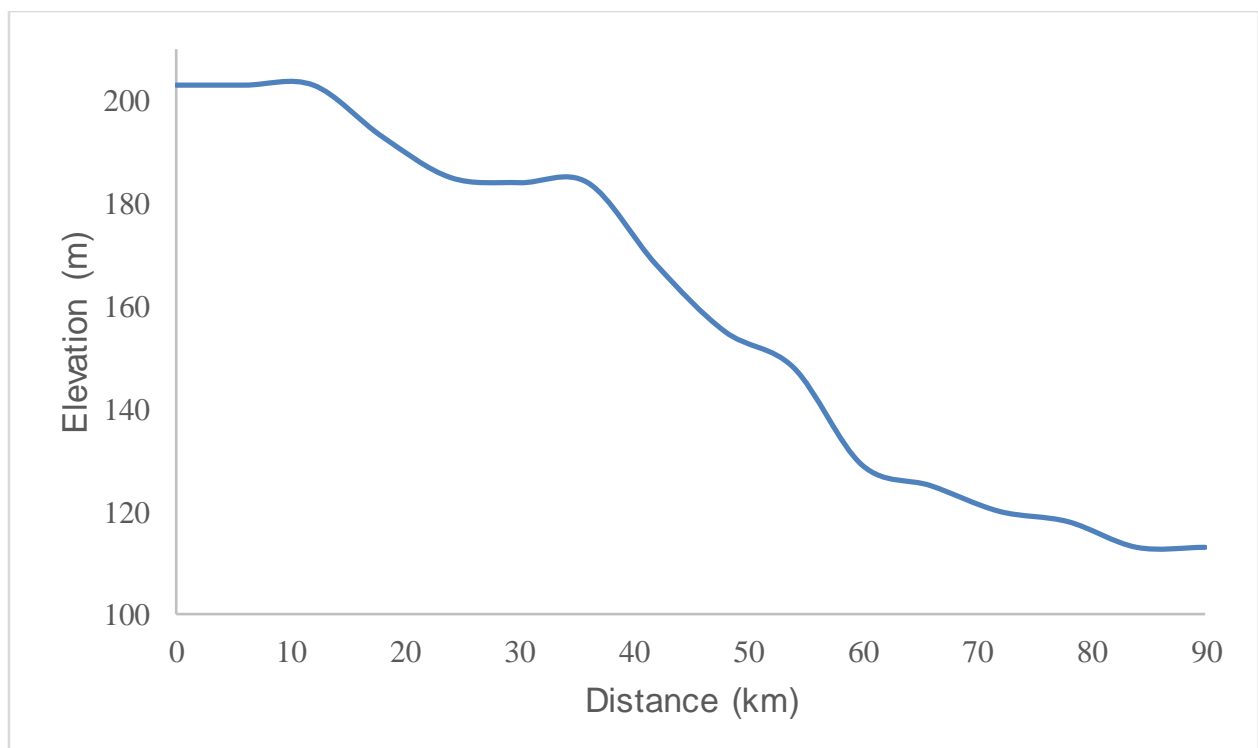

Figure 8. Elevation profile of the Gambia River.

Although most of the watershed exists in Guinea, soil data from the SOTER database was only available for Senegal. During the GSSHA process, dominant soils nearest to the Fouta Djallon plateau were extrapolated to grid cells south of the Kedougou border. In Kedougou, most of the soils were sandy loam (85.8\%), followed by sandy clay loam $(9.23 \%)$ which occur along the banks of the Gambia River. Silty loam (3.91\%) and clay loam (1.08\%) are also present in the area (Fig 9). Soils in the Guinea region were assumed as sandy loam, except for sandy clay loam near the river. Several hydrological parameters, such as hydraulic conductivity, were unavailable in the dataset. The Soil Water Characteristics program determined this and other parameters for each soil type. These values were utilized for the initial model run. Once calibration was complete, saturated $\mathrm{K}$ was adjusted to the values found in table 1.

Table 1. Hydraulic parameters for the watershed soils.

\begin{tabular}{|c|c|c|c|c|}
\hline & $\begin{array}{c}\text { Saturated Hydraulic } \\
\text { Conductivity } \\
(\mathrm{cm} / \mathrm{hr})\end{array}$ & $\begin{array}{c}\text { Wilting Point } \\
(\% \text { Vol })\end{array}$ & $\begin{array}{c}\text { Field Capacity } \\
(\% \text { Vol })\end{array}$ & $\begin{array}{c}\text { Bulk density } \\
(\mathrm{kg} / \mathrm{cubic} \text { meter })\end{array}$ \\
\hline Sandy Loam & 2.17 & 17.1 & 31.6 & 1114 \\
\hline Silty Loam & 2.23 & 11.7 & 30.7 & 1165 \\
\hline Sandy Clay Loam & 1.41 & 16.7 & 30.3 & 1248 \\
\hline Clay Loam & 0.83 & 22.2 & 36.9 & 1168 \\
\hline
\end{tabular}




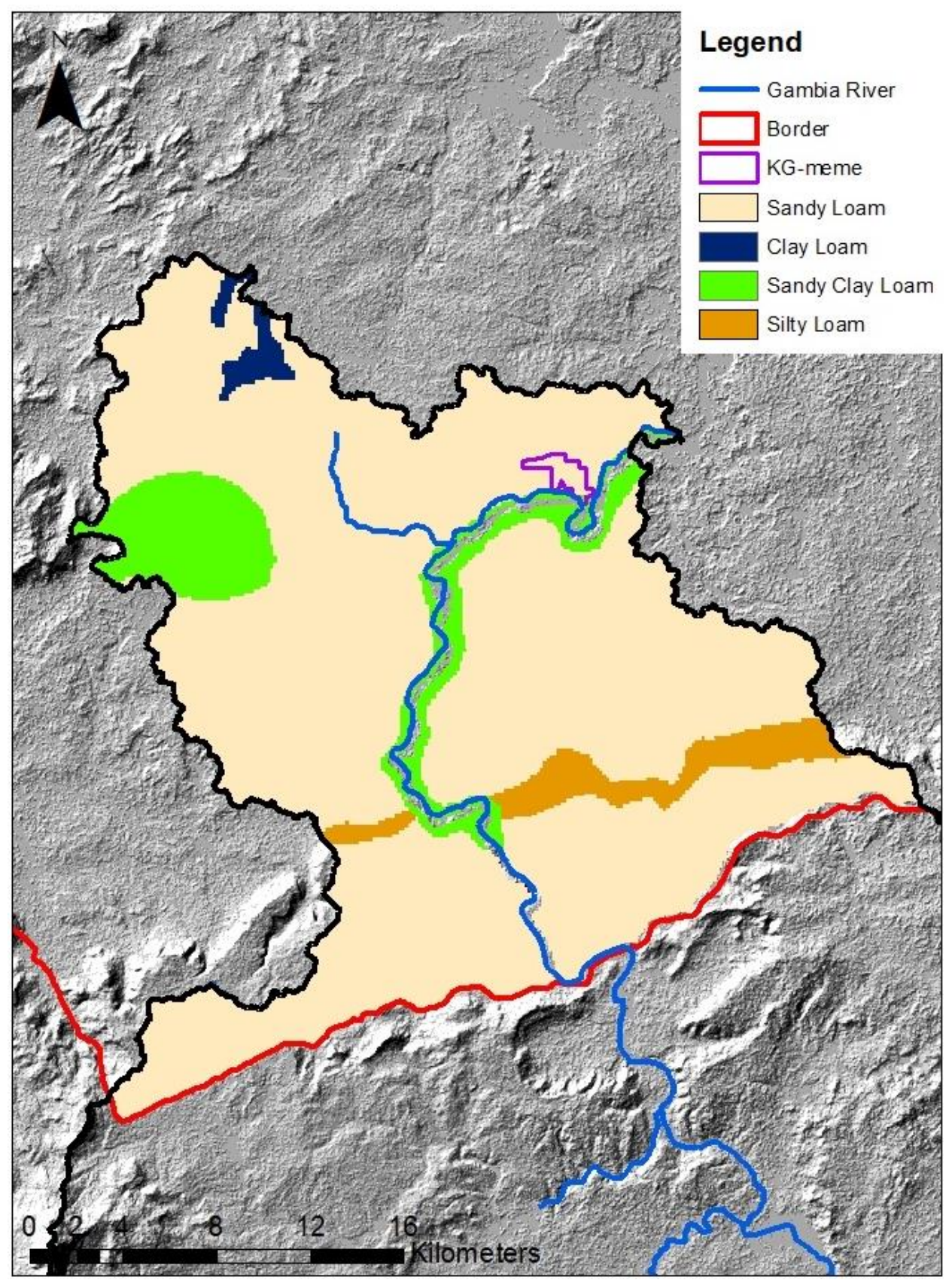

Figure 9. SOTER soil types in Kedougou. Adapted from ASTER DEM satellite imagery and SOTER data products. 
Figure 10 displays LULC change in the entire watershed between 1992 and 2015. The most significant land use changes occurred in the transition of shrub lands to open deciduous forest. Shrub lands are dominated by shrubs, grass and woody vegetation that is mainly used for grazing. These lands are preferred and essential to Pulaar cow animal herders, as the low-lying bushes provide nourishment for their livestock. Shrub land decreased from $29.29 \%$ of the watershed to $25.17 \%$ in 2015 . Conversely, open deciduous forest increased from $60.15 \%$ to $66.31 \%$ between these two years. Other land covers changed by $<2 \%$.

According to local residents, 20 years ago, KG-même was a village that consisted of several huts and forests interspersed with agricultural land. Figure 11 supports this information as it shows KG-même was completely forested in 1992. By 2015, land cover in KG-même was identified as urban area. Population growth and migration to KG-même resulted in new infrastructure, allowing it to be identified as a $2.75 \mathrm{~km}^{2}$ urban area in 2015, as shown in Figure 11. 


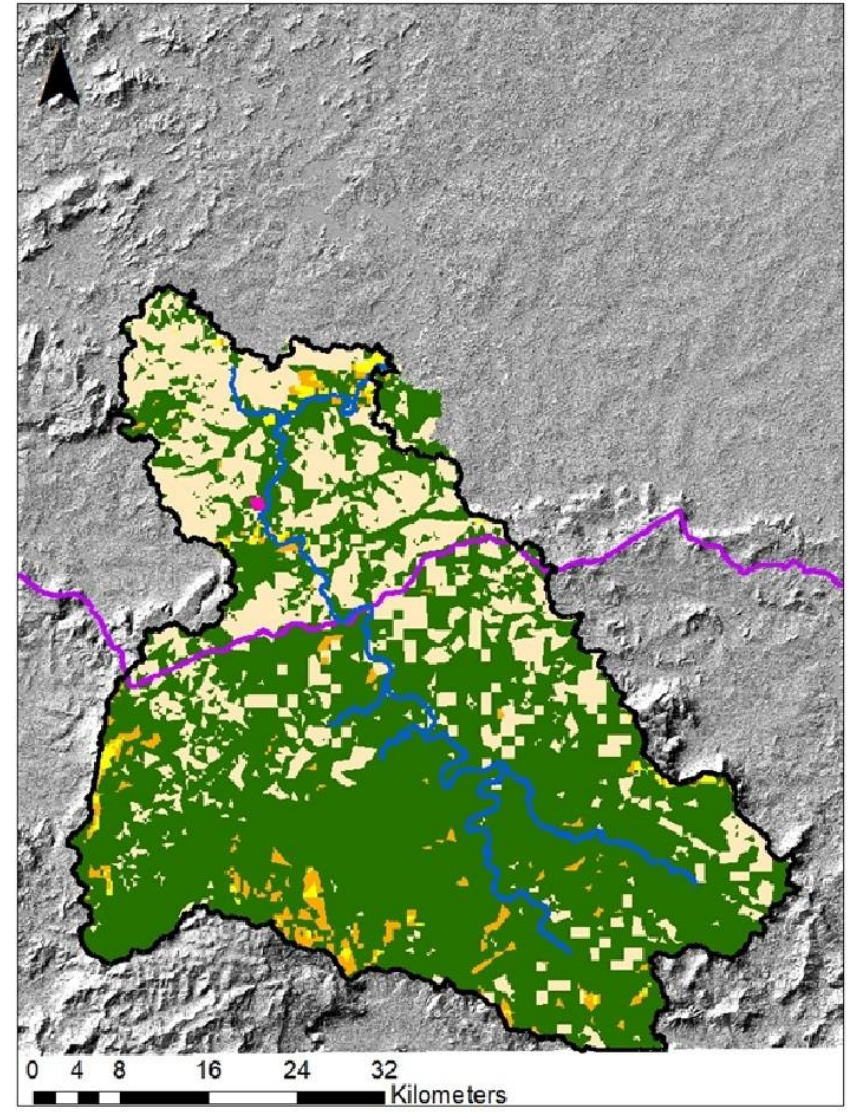

1992

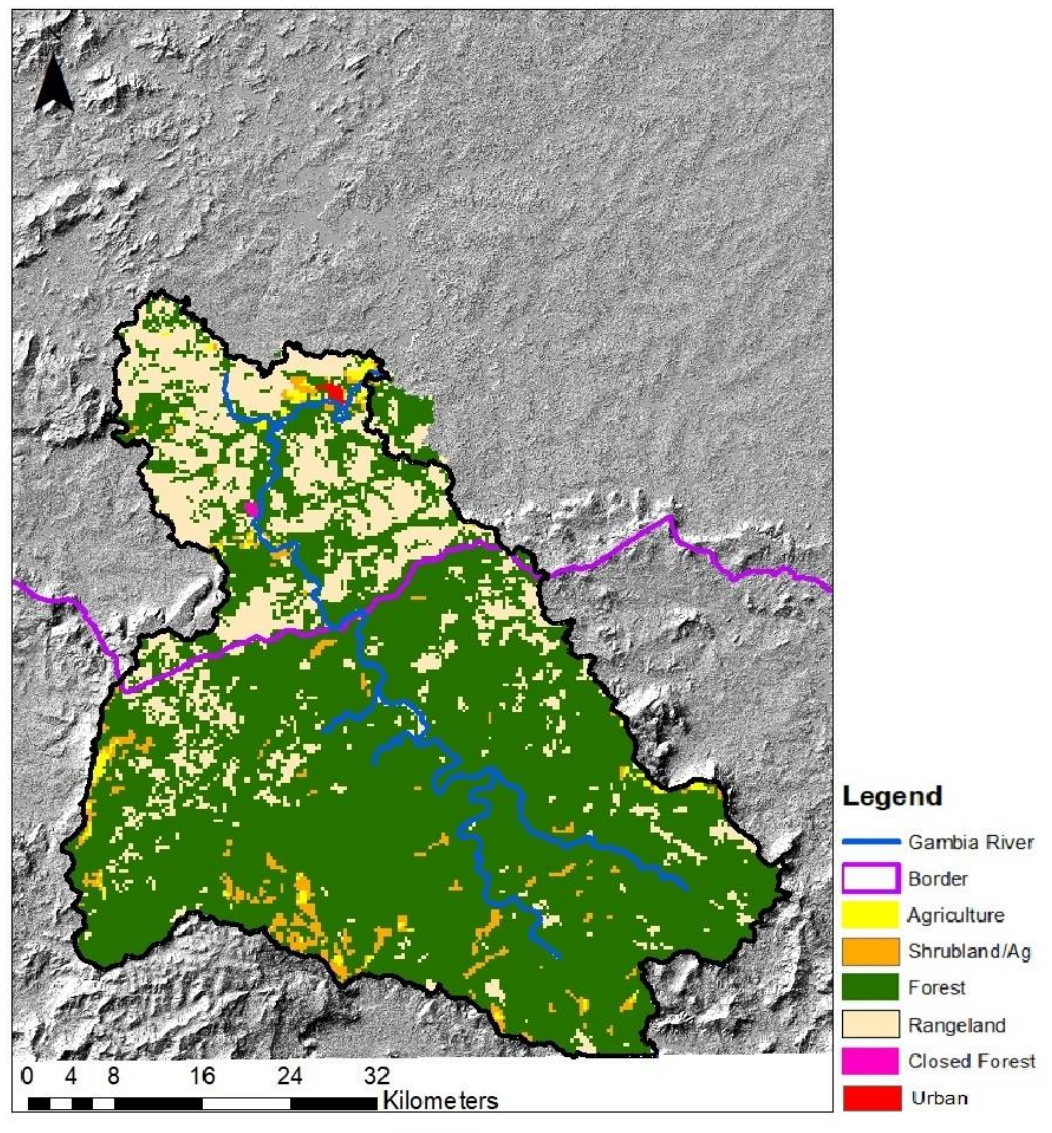

2015

Figure 10. Figure Land cover in the Gambia River watershed between 1992 and 2015. Data accessed from ESA CCI-LC viewer. 


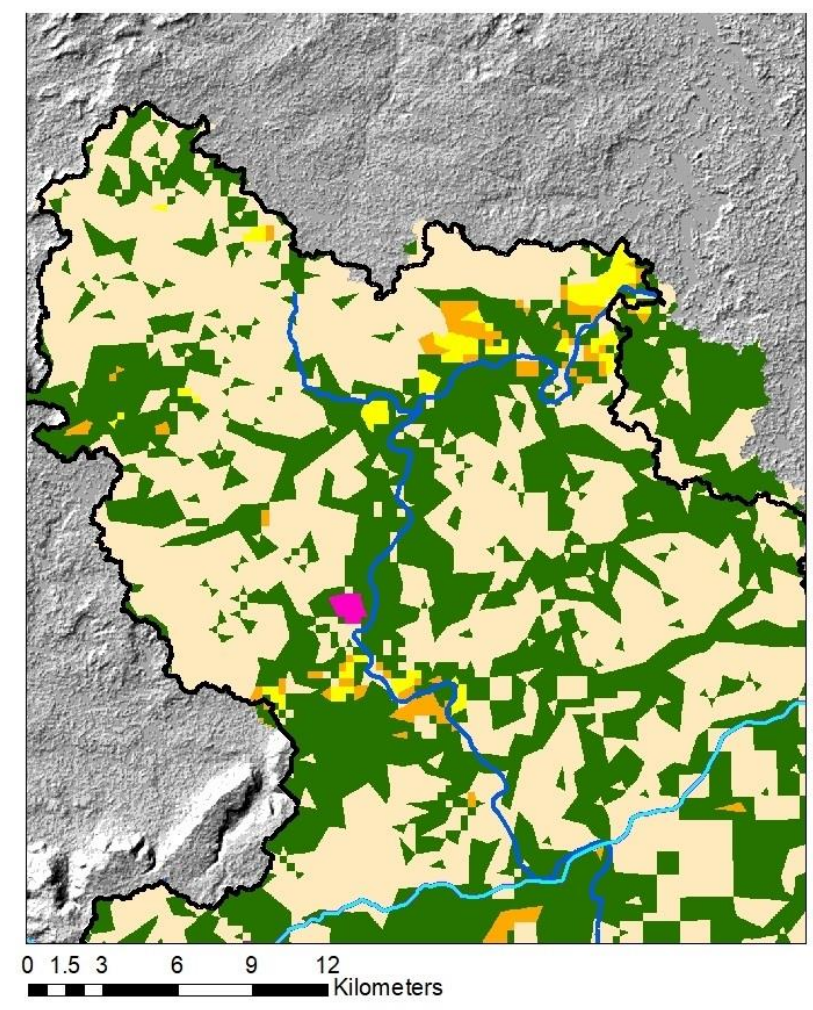

1992

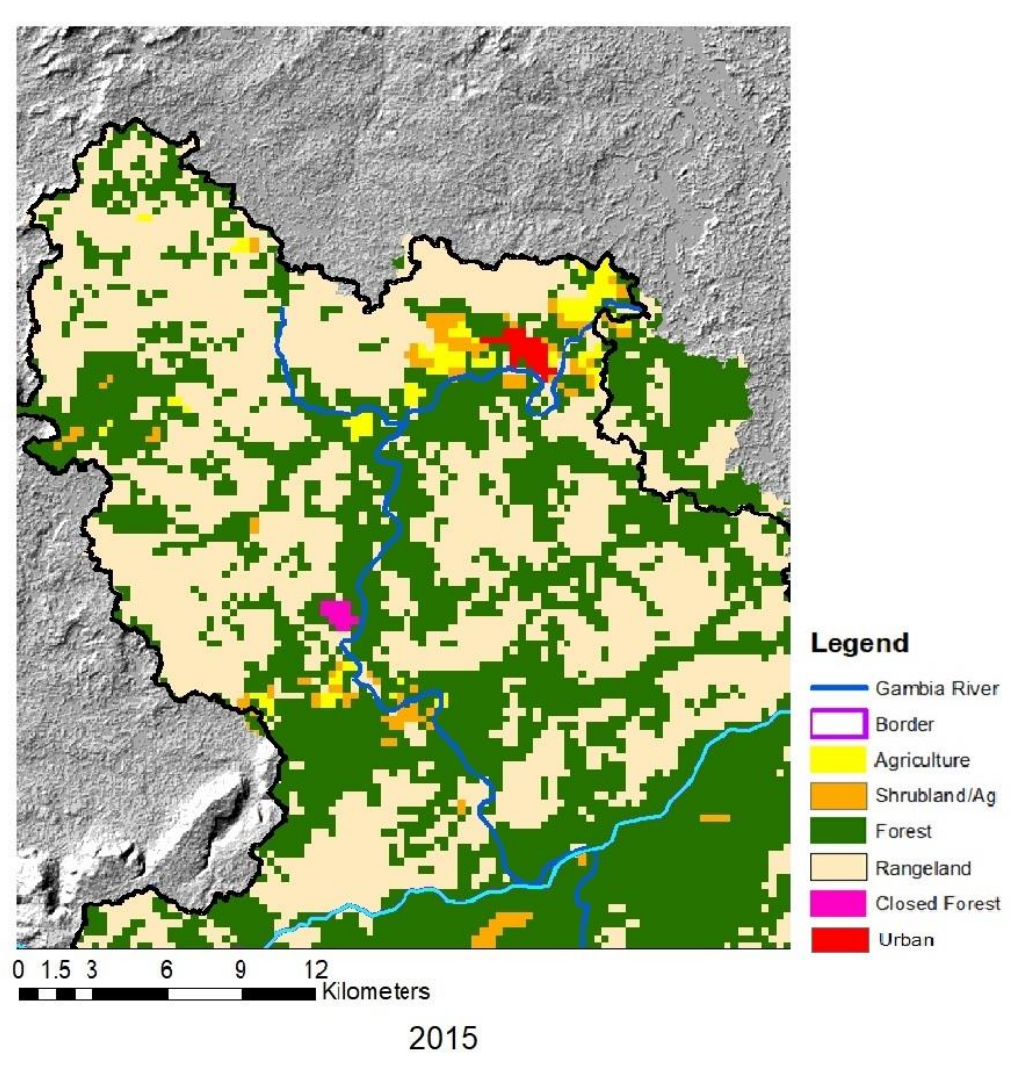

Figure 11. Land cover near KG-même between 1992 and 2015. Data accessed from ESA CCI-LC viewer. 
Once the IMERG data products were analyzed, rainfall distribution over time was graphed and averaged for each of the 10 grid cells in the dataset (Figure 12). The result was a 10-hour storm event that occurred on 08/28/2014. Using these values, a design storm hyetograph was developed. It described the ratio of rain intensity per hour to the cumulative rainfall (Fig 13). The peak rainfall occurred approximately four hours after the storm event began. Storms of varying intensities and durations occur in Senegal and are difficult to discern due to the one rain gauge in the watershed. While the rain gauge provided daily rainfall data in order to establish total rainfall for an event, the hyetograph provided information on storm duration and distribution over time.

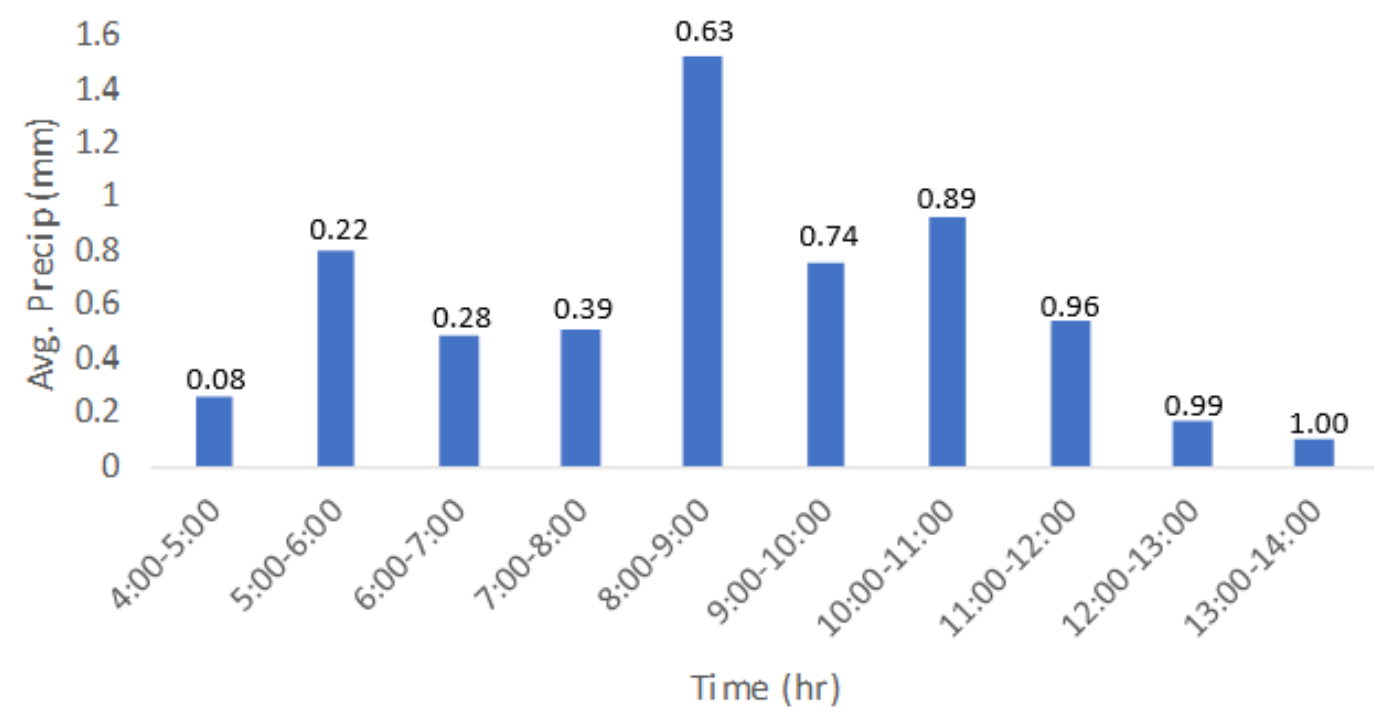

Figure 12. IMERG hourly storm distribution for Kedougou. Precipitation amounts for 10 grid cells overlaying the entire watershed were calculated for every hour of the storm. Average amounts of rainfall per hour were calculated and distributed over time as a fraction of total rainfall. 


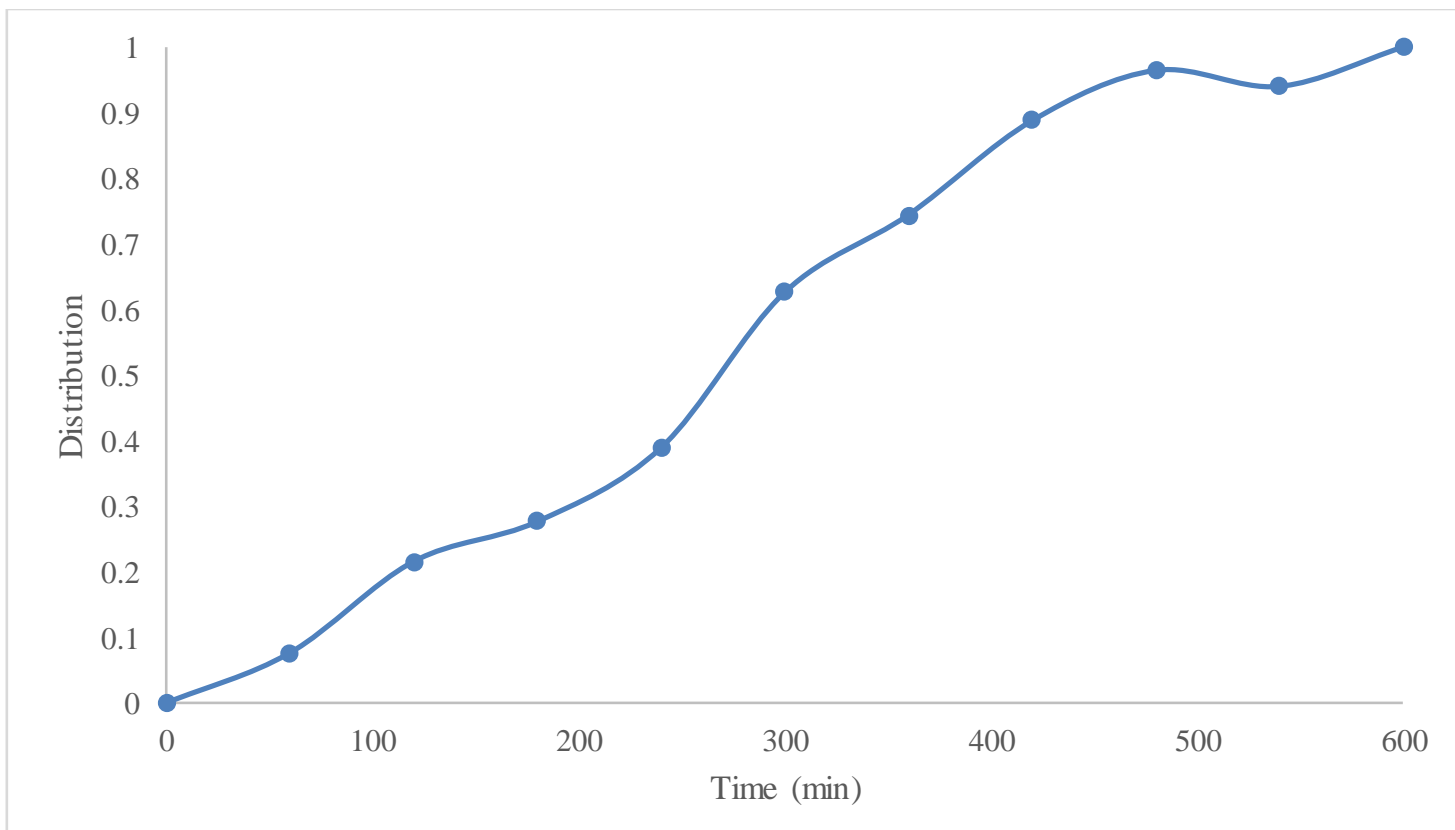

Figure 13. Kedougou design storm hyetograph displaying rainfall distribution over time

GSSHA provided hydrograph data from the outlet point. For each of the simulations, Gambia River discharge was displayed from the beginning of the storm to 60 hours post-event initiation. The Nash-Sutcliffe efficiency statistic was used to assess the accuracy of the GSSHA model. 'It is a normalized statistic that determines the relative magnitude of the residual variance ("noise") compared to the measured data variance ("information")" (Nash and Sutcliffe, 1970). It is computed as shown in Equation 1. NSE ranges between $-\infty$ and 1.0, 1.0 being the optimal value (Moriasi et al, 2007). "Values between 0.0 and 1.0 are generally viewed as acceptable levels of performance, whereas values less than 0.0 indicates that the mean observed value is a better predictor than the simulated value, which indicates unacceptable performance" (Moriasi et al., 2007).

$$
\mathrm{NSE}=1-\left[\frac{\sum_{i=1}^{n}\left(Y_{i}^{o b s}-Y_{i}^{\text {sim }}\right)^{2}}{\sum_{i=1}^{n}\left(Y_{i}^{\text {obs }}-Y^{\text {mean }}\right)^{2}}\right]
$$

Figure 14 compares the simulated and observed discharge at the Kedougou gauging station. As stated earlier, the outlet point at the gauging station was used for calibration only. The watershed did not encompass KG-même at this point. The NSE for the 1992 and 2015 simulations were determined to be -0.533 and -0.449 , respectively. For a $63 \mathrm{~mm}$ event, simulated discharge reached a peak of $424 \mathrm{~m}^{3} / \mathrm{s}$ in 1992 , whereas a peak of $416 \mathrm{~m}^{3} / \mathrm{s}$ was determined for 2015 . These values were approximate to the 
observed peak of $427 \mathrm{~m}^{3} / \mathrm{s}$, although there was a pronounced lag time in the simulated data.

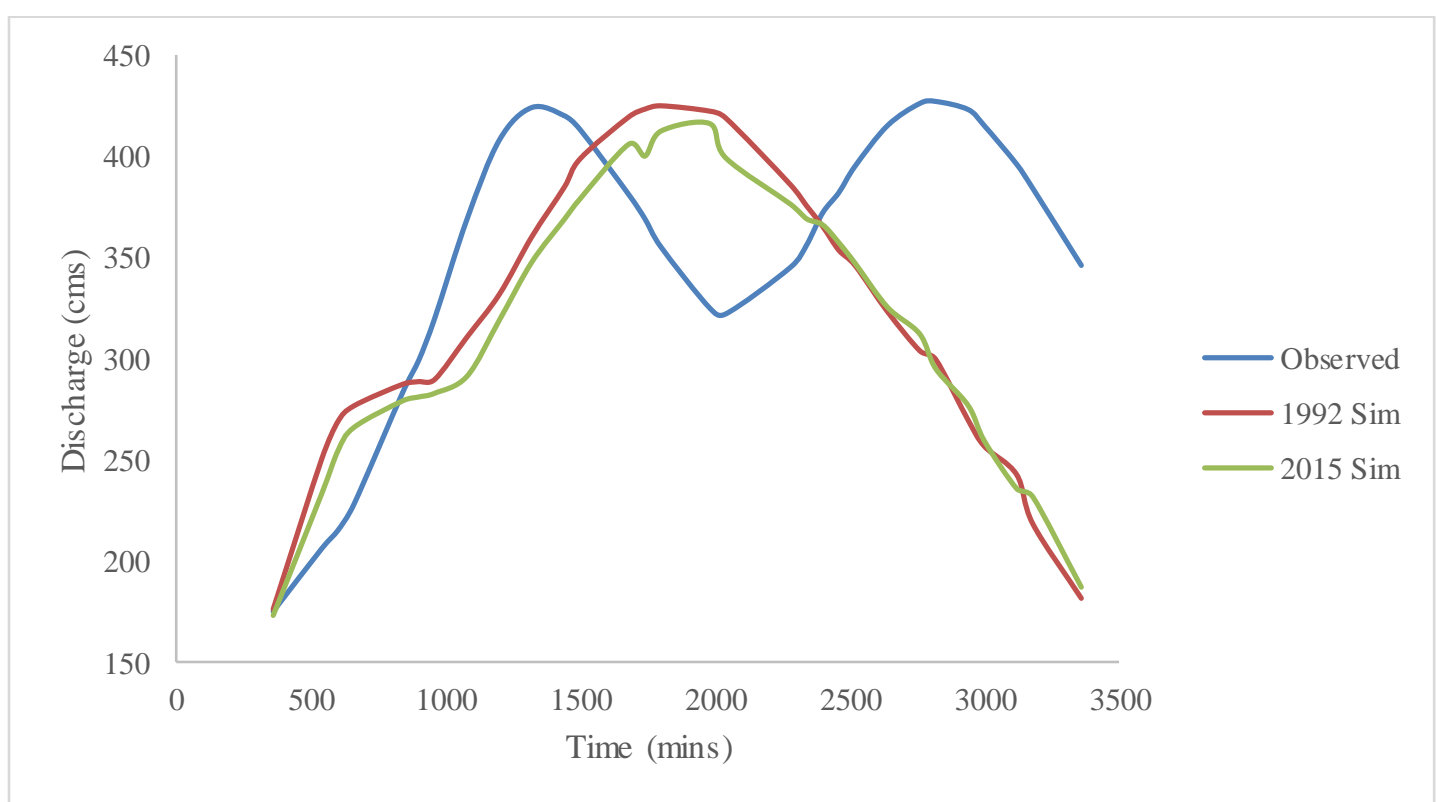

Figure 14. Hydrograph at Kedougou gauging station. The two peaks found in the observed data are not observed in the model simulation. Both simulations were relatively close to observed peak discharge.

The outlet point was moved 10-km downstream after calibration, and the hydrograph comparisons are shown in Figure 15. The NSE between the 1992 land cover and observed discharge was 0.103 , whereas the 2015 and 2050 land covers had an NSE of 0.026 and -0.003 . Increased urban land cover in the 2050 scenario may have affected the NSE value as urban area increased $1.5 \mathrm{x}$ its original size. Once the outlet point was moved downstream, the GSSHA model reached acceptable levels of performance for historic and present land use situations, according to the NSE (0.0-1.0). The simulated hydrographs follow the trend of the observed discharge, where multiple peaks and dips occur. However, only the 1992 land cover reached and even exceeded observed peak discharge at $432 \mathrm{~m}^{3} / \mathrm{s}$. 


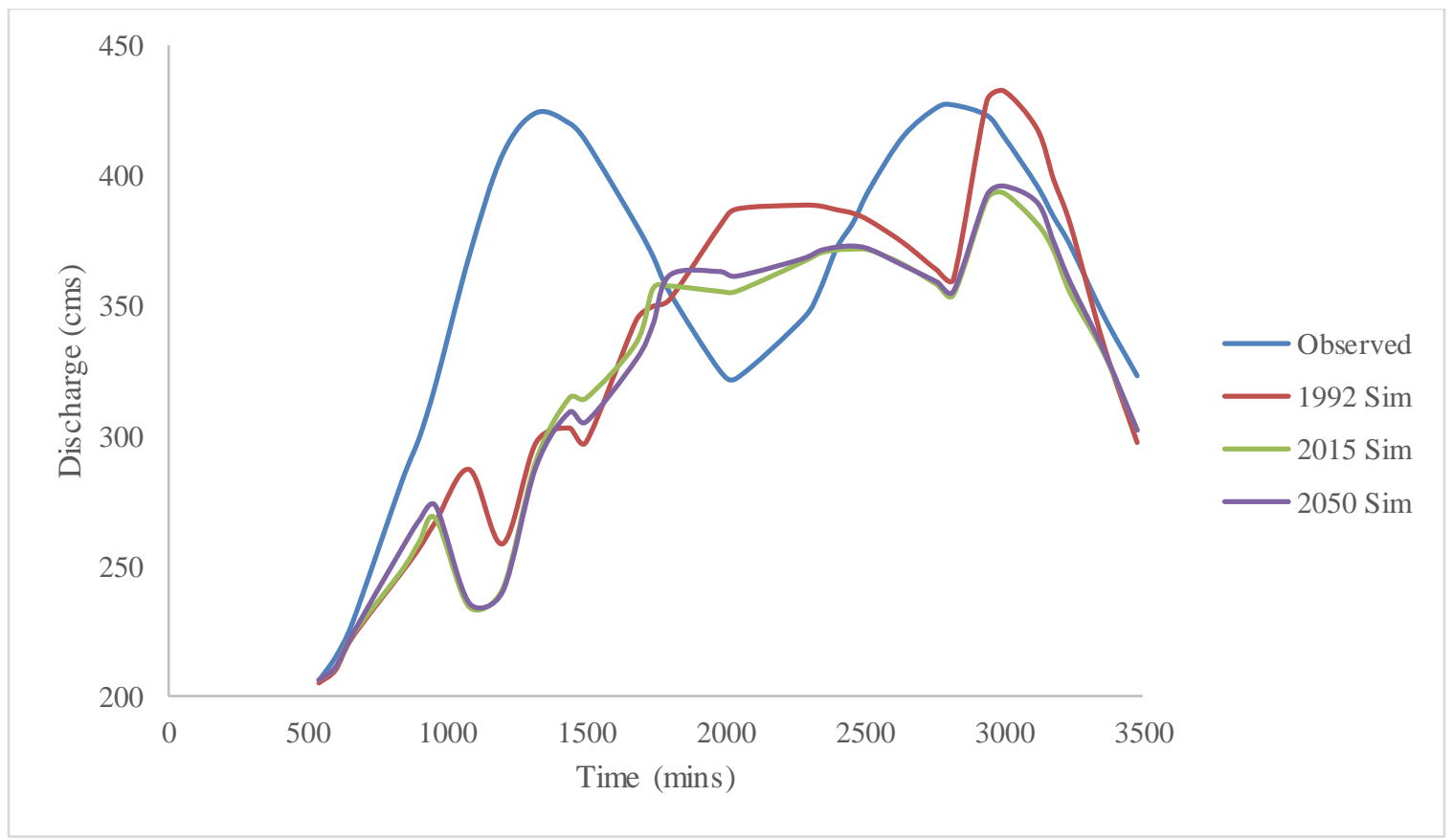

Figure 15. Hydrograph of KG-même downstream outlet. After moving the outlet downstream, there was more variation in the hydrographs. Though, only the 1992 event reach observed peak discharge, each hydrograph maintained similar undulation.

Figure 16 displays the spatial extent and depth of inundation in the Gambia River watershed in 1992. These figures do not show floods occurring at the same time. They display maximum flood depth in each grid cell for any given point in time. Multiple tributaries of the river show flooding; however, along the main stretch of the Gambia river, flooding occurs near and just upstream of Kedougou. In 1992, before urbanization, maximum flood depth reached $4.29 \mathrm{~m}$. 

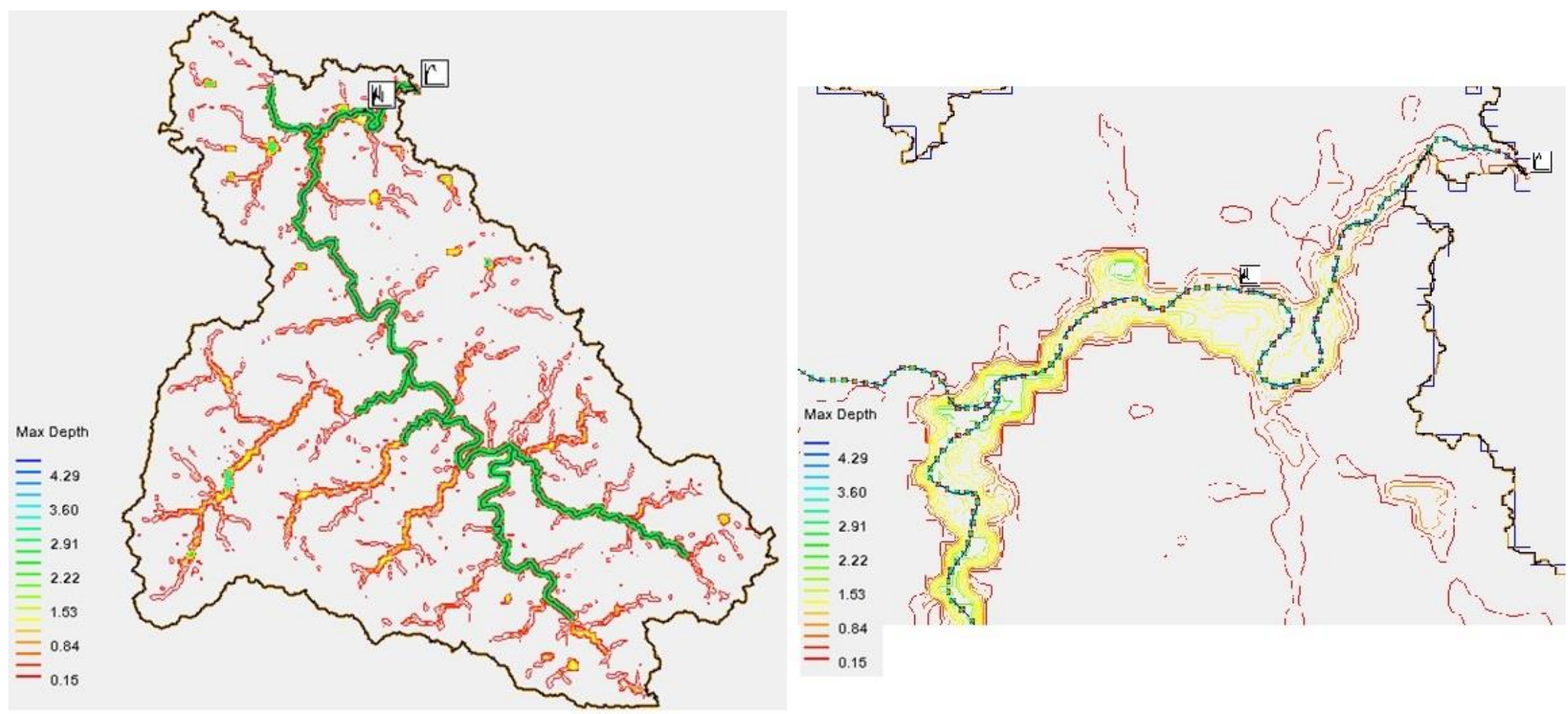

Figure 16. Kedougou inundation extent and depth (1992). These are the GSSHA results from a 63 mm rain event. It is evident that many of the tributaries for the Gambia River flood. 
Figure 17 shows inundation during the 2015 land cover scenario. When compared to 1992, flooding and maximum flood depth were less severe. The year 2015 experienced a maximum overland depth of $4.16 \mathrm{~m}$.
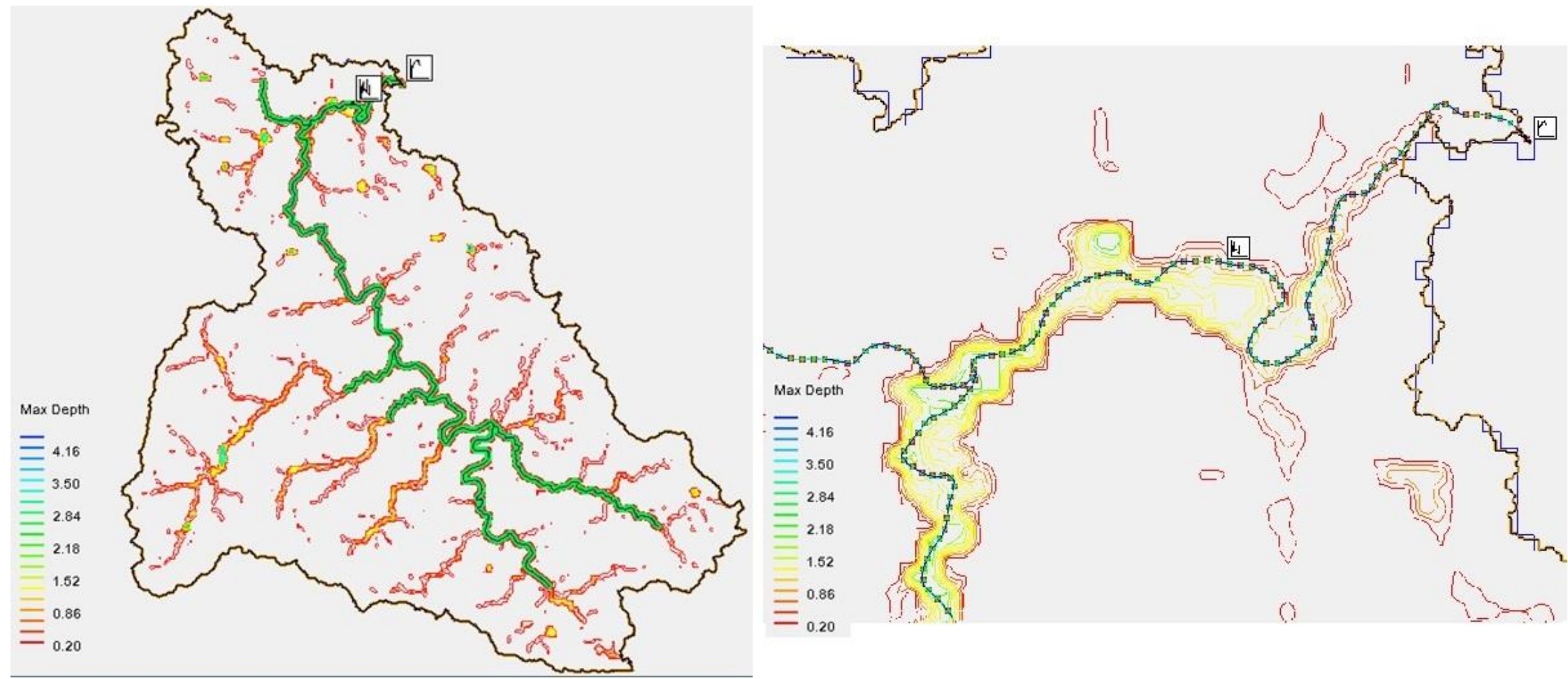

Figure 17. Inundation extent and depth (2015). Same $63 \mathrm{~mm}$ event, but flooding and max depth are less intense in the 2015 and 2050 scenarios. 
Changes from forest or agricultural land to urban area were projected to 2050, at the same rate between 1992 and 2015 . A 23year gap existed between 1992 and 2015, so urban area was increased 150\% because of the 35-year gap between 2015 and 2050. Figure 18 shows the 2050 land cover scenario maintained nearly identical flood distribution and depth patterns as 2015 . Maximum depth also reached $4.16 \mathrm{~m}$.
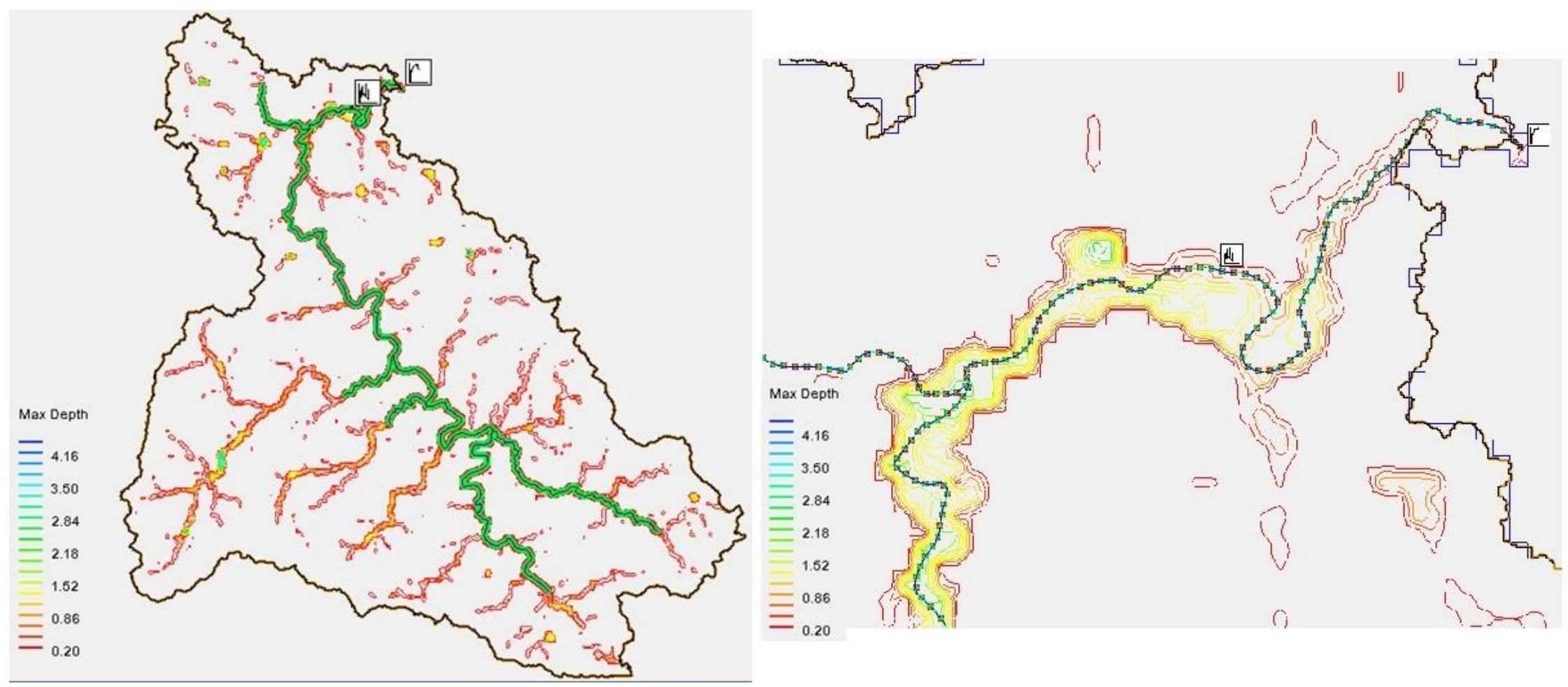

Figure 18. Inundation extent and depth (2050). Similar to 2015 values. 
Figure 19 shows villages upstream of KG-même that would be affected by flooding. Some of these villages are significant due to larger village populations and important health outposts, such as Itato to the southwest and Fadiga to the west of KGmême. Inundation in 1992 was more extensive and deeper than 2015 and 2050.

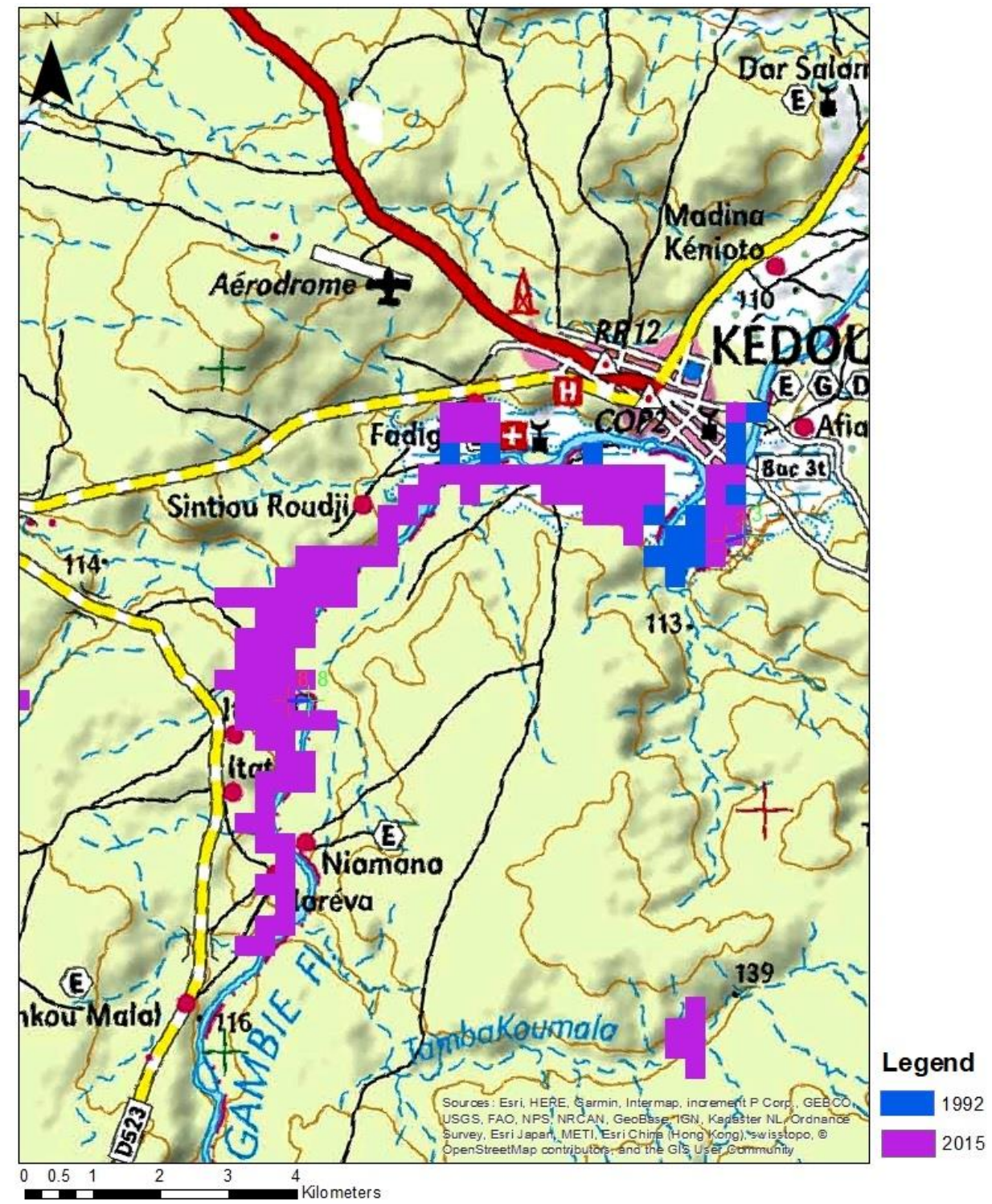

Figure 19. Upstream villages affected by inundation 
After simulating the watershed, the GSSHA model was validated against SAR imagery from the Sentinel-1 Satellite. This mission maintains a 12 day repeat cycle causing pre and post flood images to be limited. Fortunately, the satellite observed a flooding event on 08/18/16 and was compared to an image on 08/06/16 shown in Fig. 20. Psomiadis (2016) explained, "The Sentinel-1 SAR data product utilizes the sensitivity of the backscatter signal to open water. Through radar intensity imagery, in the absence of wind, the specular reflection of C-band signals over open water means that the signal is significantly lower than average." The Sentinel-1 mission cannot determine depth of flooding as it does extent. So, there is significant importance for these detailed hydrologic models. Figure 21 is the same flooded image, but displays waterbodies and inundation in red.

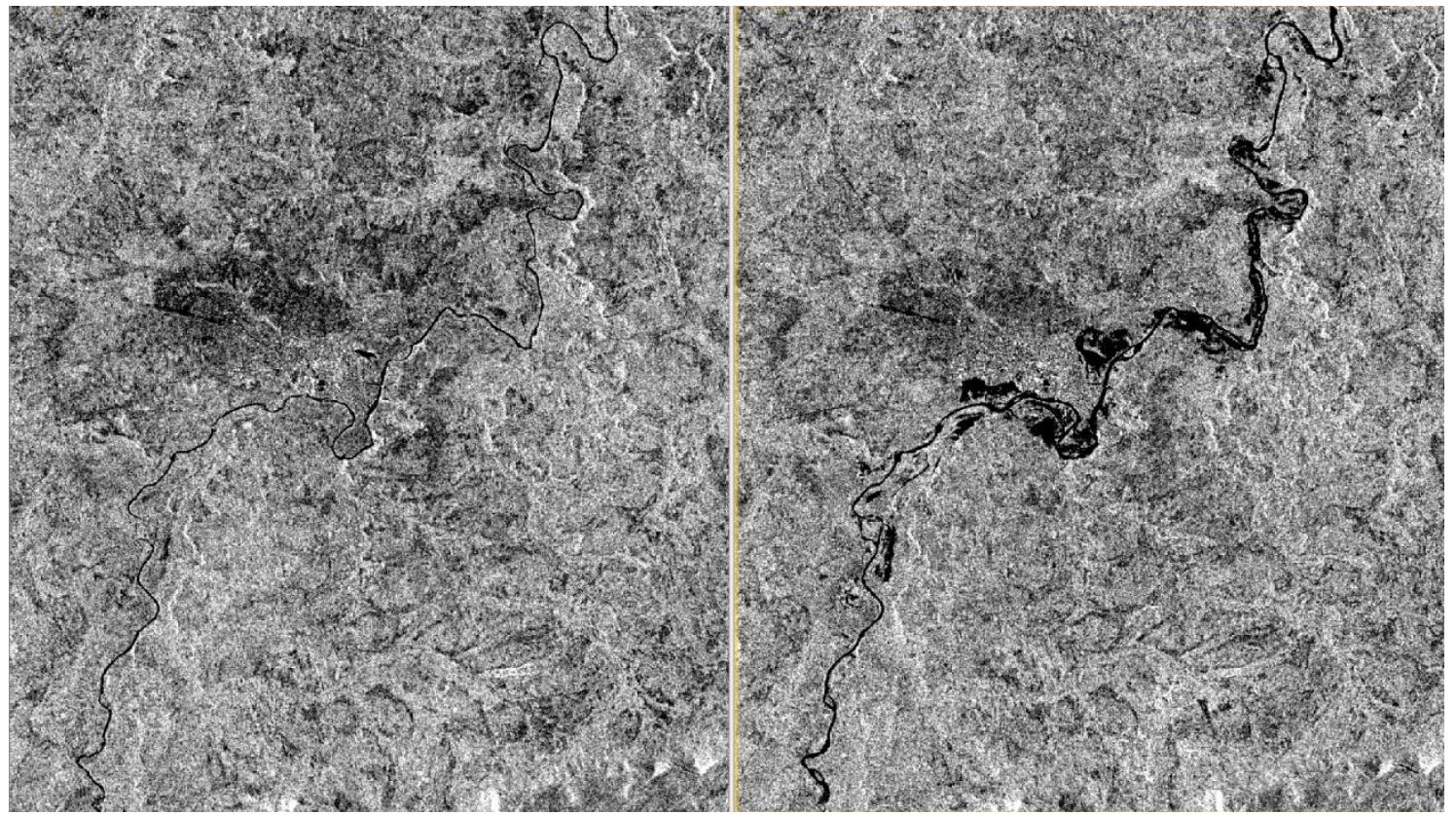

Figure 20. $20 \mathrm{~m}$ resolution SAR based imagery of KG-même before and after a flood that occurred between 08/06/18 (left) and 08/18/18 (right). 


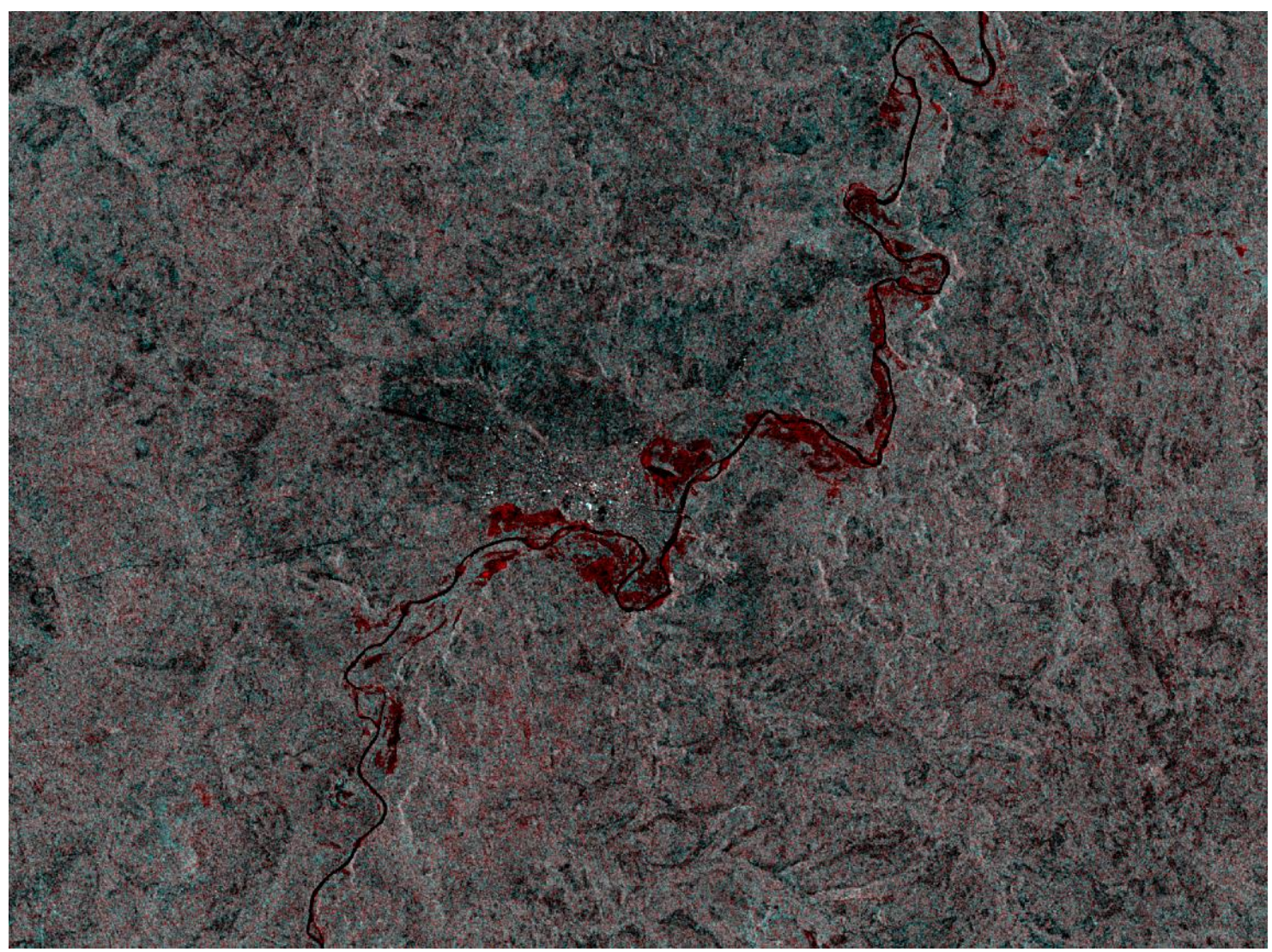

Figure 21. Flooding of the Gambia River and other waterbodies shown in red. 
Since the 1992 land cover scenario displayed more flooding, it was compared to the SAR-based inundation, as seen in the left image. Analysis showed that much of the simulated flood output correlated with observed data. However, the storm on 08/18/16 had more flooding downstream than the simulated 63-mm rainfall event. A 100-mm storm event using 1992 was run in GSSHA to assess flooding downstream of KG-même and is shown on the right.
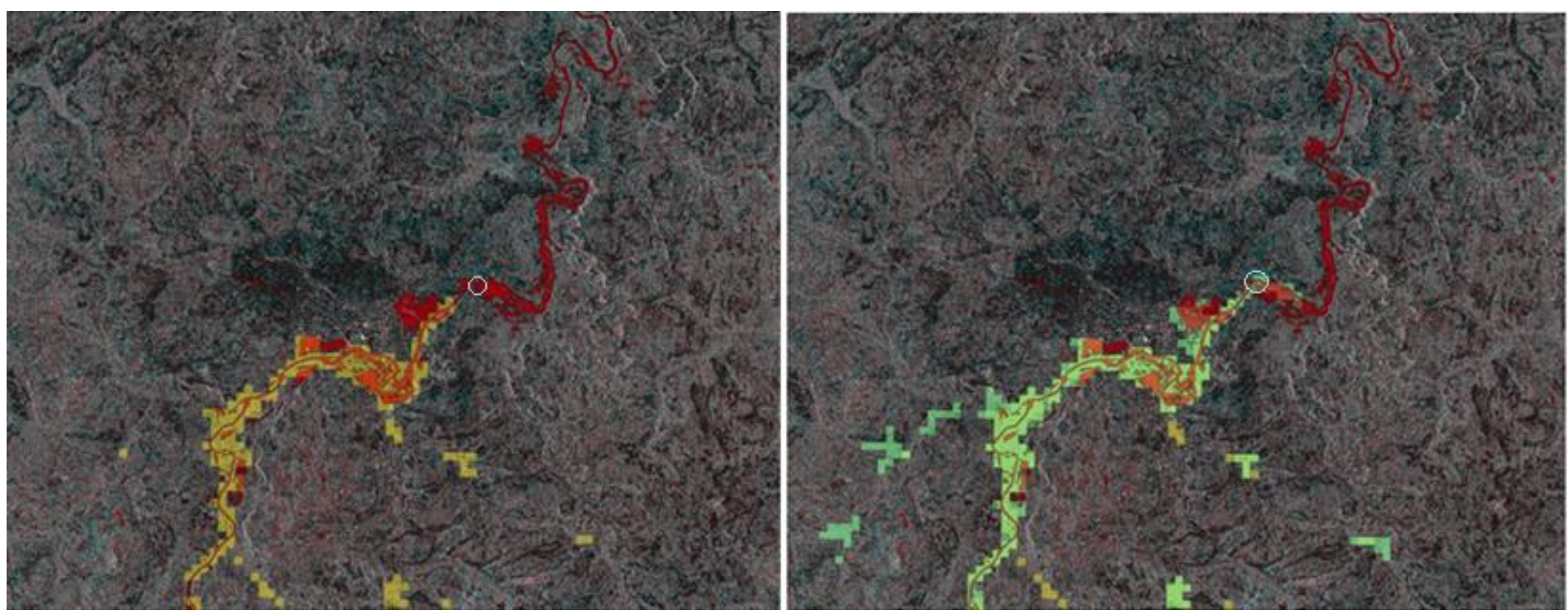

Figure 22. GSSHA output compared to observed flooding. The image on the left shows flooding from a 63-mm event in a 1992 land use scenario. The image on the right is from a $100 \mathrm{~mm}$ rain event, also during 1992. The yellow and green colors represent GSSHA simulated flood extent $(>1 \mathrm{~m})$. Outlet shown in light blue. Further studies should downscale the SAR imagery to better align with GSSHA output. 
In addition, the hydrograph for the $100 \mathrm{~mm}$ storm event showed opposite results from the less intense storm. The higher intensity, same duration storm caused a $\sim 200 \mathrm{~m}^{3} / \mathrm{s}$ increase in peak discharge after urbanization. Peak discharge in 1992 was $1,086 \mathrm{~m}^{3} / \mathrm{s}$, and was 1,263 in 2015 . This was further validated as the 2050 land cover scenario also exceeded 1992 peak discharge. However, it was insignificantly different from the 2015 land cover scenario, so it was not included in Figure 23.

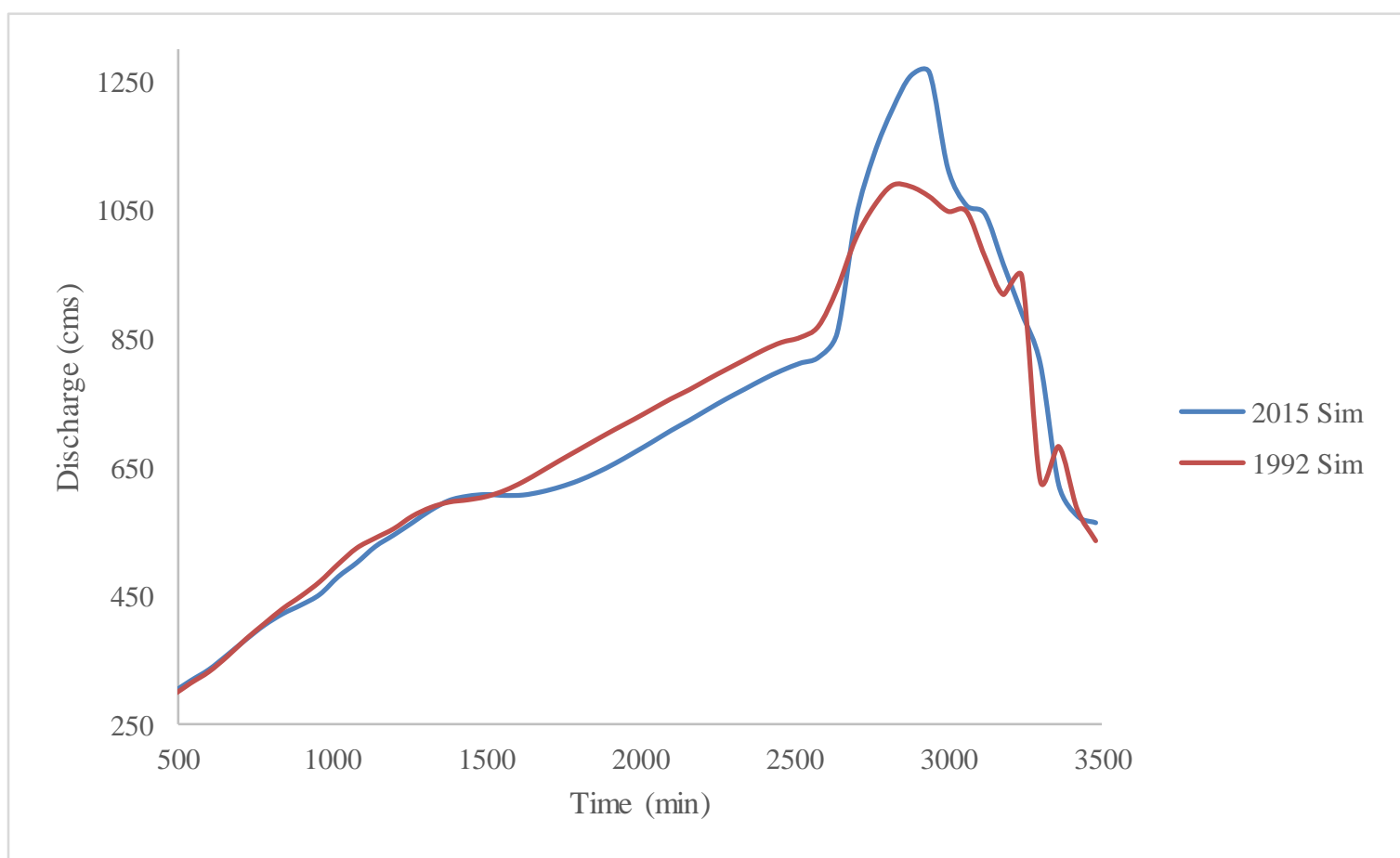

Figure 23. GSSHA verification simulations displayed that urbanization may increase runoff when there is a larger storm, $\sim 100 \mathrm{~mm}$ of precipitation. 


\section{Discussion}

Urbanization within this watershed has only occurred in KG-même. According to the land cover data, between 1992 and 2015, the urban area in KG-même grew to 2.75 $\mathrm{km}^{2}$, still $<1 \%$ of the $2,488 \mathrm{~km}^{2}$ watershed. Over $70 \%$ of the watershed is in the Fouta Djallon plateau. This heavily forested plateau contains sparsely located villages and has actually experienced an increase in foliage between 1992 and 2015. Literature review and precipitation trends indicate that a drought occurred in West Africa during the 1980s. According to Diop et al. (2015), there have been three major sequences of rainfall occurrence at the Kedougou gauging station:

1. "1921-1968: overall surplus phase where annual totals are above average. The deficit years during this period correspond to the drought of the years 1941-1944 with deficits of the order of $10 \%$.

2. 1968-1990: a very sharp decline in rainfall inputs culminated in 1983, a year with a deficit of $25 \%$. Very few years in this sequence reach the inter-annual average of 1921-1968.

3. 1990-2014: a gradual increase in rainfall despite the 2002 deficit"

On average, between 1921 and 2014, the Gambia River basin received 1160-1540 $\mathrm{mm}$ of rainfall. During the period from 1921 to 1967 , it varied from $1650 \mathrm{~mm}$ to 1200 $\mathrm{mm}$. Between 1968 and 2014, it fluctuated between $1450 \mathrm{~mm}$ and $1100 \mathrm{~mm}$. Over the last fifteen years, the increase in rainfall remains very low in the basin (Diop et al., 2015).

The decrease in rainfall during 1968-1990 influenced vegetation patterns for the 1992 land cover. Shrub land was $4.12 \%$ higher in 1992 than 2015. The reduction in rainfall caused forests to diminish and allowed the growth of shrubs and other droughtresistant vegetation (Hanke et al., 2016). A higher percentage of shrubland may have resulted in increased river discharge and flood extent and depth. Figures 15-19 show that both peak discharge and maximum flood depth are larger in 1992 than 2015.

Considering most of the watershed is in Guinea, LULC change would have to occur in the Fouta Djallon plateau to see a significant change in streamflow and inundation. Climate change can influence land cover patterns by both removing or preserving certain flora. Based on the model, it was evident that the drought that occurred before 1992 killed forest cover, but encouraged the growth of drought-resistant shrubs. The model showed that climate change influences land cover and increases runoff, evident during lower intensity storms.

These results are comparable to previous studies that determined a phenomenon known as the "Sahelian paradox." West Africa is differentiated by climate zones based on precipitation rates (Fig 21). "Average precipitation for the Guinean domain falls between 1400-2700 mm, the Sudanian zone ranges from 950-1400 mm, and the Sahelian zone receives 450-1050 mm" (Ogungbenro and Morakinyo, 2014). "During the second half of the 20th century, the Sahel underwent a severe rainfall deficit, considered as the largest multi-decadal drought of the last century (Hulme et al., 2001; Nicholson et al., 1998), 
with extreme droughts in 1972-1973 and again in 1983-1984 that strongly impacted ecosystems, water availability, fodder resources and populations living in these areas" (Nicholson, 2005). According to Gal et al. (2017), "responses induced by this deficit result in contrasted effects depending on the eco-climatic zone considered." "If the Sudano-Guinean zone displayed an expected decrease of surface runoff following the drought, the opposite situation was observed in the Sahelian zone" (Descroix et al., 2009; Séguis et al., 2002, 2011). However, the Gambia River watershed is located in the Sudano-Guinean climate zone. The comparisons between the 1992 and 2015 land cover scenarios may support the notion that the Sahelian paradox was not limited to the Sahel. The lack of rainfall during these droughts affected the forest cover of Kedougou, resulting in increased runoff and streamflow during 1992 as opposed to 2015 (low intensity storms).

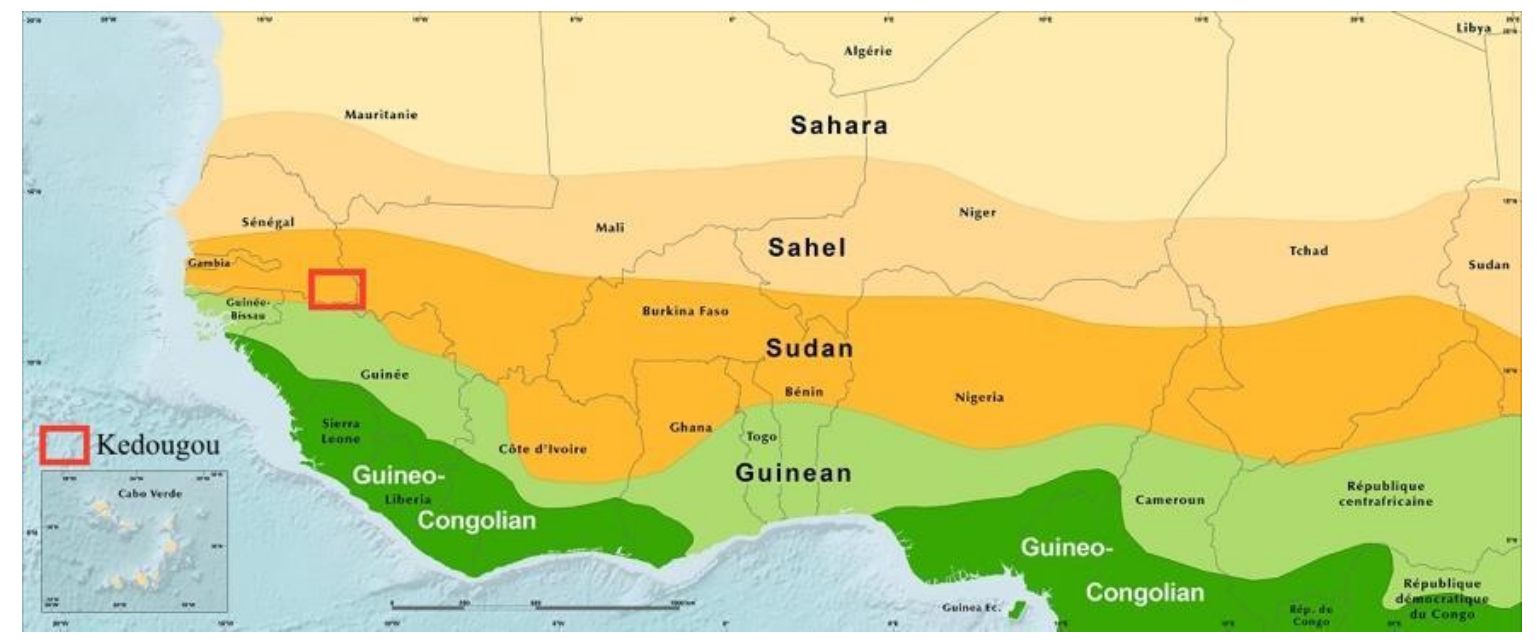

Figure 24. Climate zones in West Africa. Each are differentiated by annual precipitation amounts, increasing further south. Accessed from the USGS website

Bodian et al. (2018), investigated the effects of climate change on the streamflow of the Gambia River basin. At the 2050 horizon, the authors determined that streamflow in the Gambia River basin would decrease 22 to $26 \%$. Based on the GR4J hydrologic model used by the authors, a combination of temperature increase and annual rainfall decrease resulted in significant streamflow reduction. However, "GR4J does not consider the dynamics of land use in simulating discharge and the future impacts LULC change can have on runoff" (Bodian et al., 2018). Based on precipitation trends from the mid1980s to early 1990s (Fig. 6), decreased rainfall and drought have the capacity to alter land cover in a way that actually increases streamflow and downstream flooding. Climate change results in higher temperatures and lower rainfall, therefore average annual streamflow may be lower than previous years. However, climate change may alter land cover thereby reducing evapotranspiration and increasing streamflow and flooding during heavy precipitation events. While the annual average precipitation may decrease, climate 
change induces more frequent extreme rainfall events which may increase food insecurity and shelter needs.

Contrarily, model testing showed that, during extreme precipitation events $(\sim 100$ $\mathrm{mm})$, streamflow increased by approximately $20 \%$ in 2015 . Flooding was extensive and continued downstream, in correlation with SAR data. The only parameter adjusted was rainfall amount; the output displayed an opposing situation to the first model run. Based on these results, it can be inferred that urbanization during large rainfall events does affect local hydrology by increasing surface runoff, discharge, and inundation.

\section{GSSHA}

The pre-calibrated GSSHA model proved to be inaccurate due to NSE values of -0.533 (1992) and -0.449 (2015). However, once calibrated, NSE values proved that the simulation was sufficient with values of 0.103 (1992) and 0.026 (2015). Due to lack of data, estimation of precipitation trends were difficult. In the $\sim 2,500 \mathrm{~km}^{2}$ watershed, the only reliable rain gauge with extensive data was found at the Kedougou airport.

Additionally, only daily precipitation values were available. Stream gauge data were just as insufficient in terms of availability and temporal resolution. In order to properly calibrate the model, corresponding precipitation and discharge data were necessary. This data was only sufficient enough starting from the early 1990 s to 2003 . Using the IMERG data allowed the construction of a design storm hyetograph on a sub-hourly time scale. This precipitation method proved to provide the most accurate results, as the rain gauge method was limited due to the existence of one rain gauge in the watershed. Using the IMERG data, rain gauges were placed at the center of each cell; however, the distance between rain gauges and lack of upstream rainfall data did not provide accurate results. In addition, the uniform rainfall distribution method was inaccurate as there were difficulties and inaccuracies in determining how to distribute a daily rainfall amount over time. Calibration was possible due to the IMERG designed hyetograph and hourly Q values from the Kedougou stream gauge.

Calibrated parameters displayed some interesting results. All calibrated numbers were within the recommended minimum and maximum values for land cover, saturated hydraulic conductivity, and initial moisture content. Surface roughness values for land cover were similar to the associated values found in literature. In stark contrast, saturated hydraulic conductivity for soil types were vastly different from the Soil Water Characteristics estimated K. Sandy loam, $85 \%$ of the soil found in Kedougou, obtained calibrated values of $0.048 \mathrm{~cm} / \mathrm{hr}$. This corresponds to conductivity values found in clay soils. This anomaly may have been due to the existence of laterite in the area, especially in the Guinean parts of the watershed. "Bowé - laterite-capped plateaus that characterize much of Guinea's landscapes - accounts for 13\% of Guinea's land surface" (USGS, 2019). Soil moisture content was also determined through calibration. Manual adjustments were completed for improved accuracy.

Manning's roughness coefficient for land cover was both automatically and manually calibrated for higher accuracy. Each of these values was within the acceptable ranges of surface roughness found in Appendix B. Therefore, the largest sources of error 
in this model may be due to rainfall distribution and saturated hydraulic conductivity. If rain gauges were more available and maintained in the mountains of Guinea and smaller villages in the area, this would improve model accuracy. Hydraulic conductivity was low, therefore decreasing infiltration rates and increasing runoff. The clay-like $\mathrm{K}$ values for sandy loam may have been due to the existence of laterite in the area or initial soil moisture content. August is the peak of rainy season in Kedougou, and it can be assumed that soils are thoroughly saturated before event occurrence. Calibrated soil moisture content was found to be $\sim 45 \%$ of the total porosity in sandy loam. These errors may have increased runoff rates, while decreasing real world infiltration amounts.

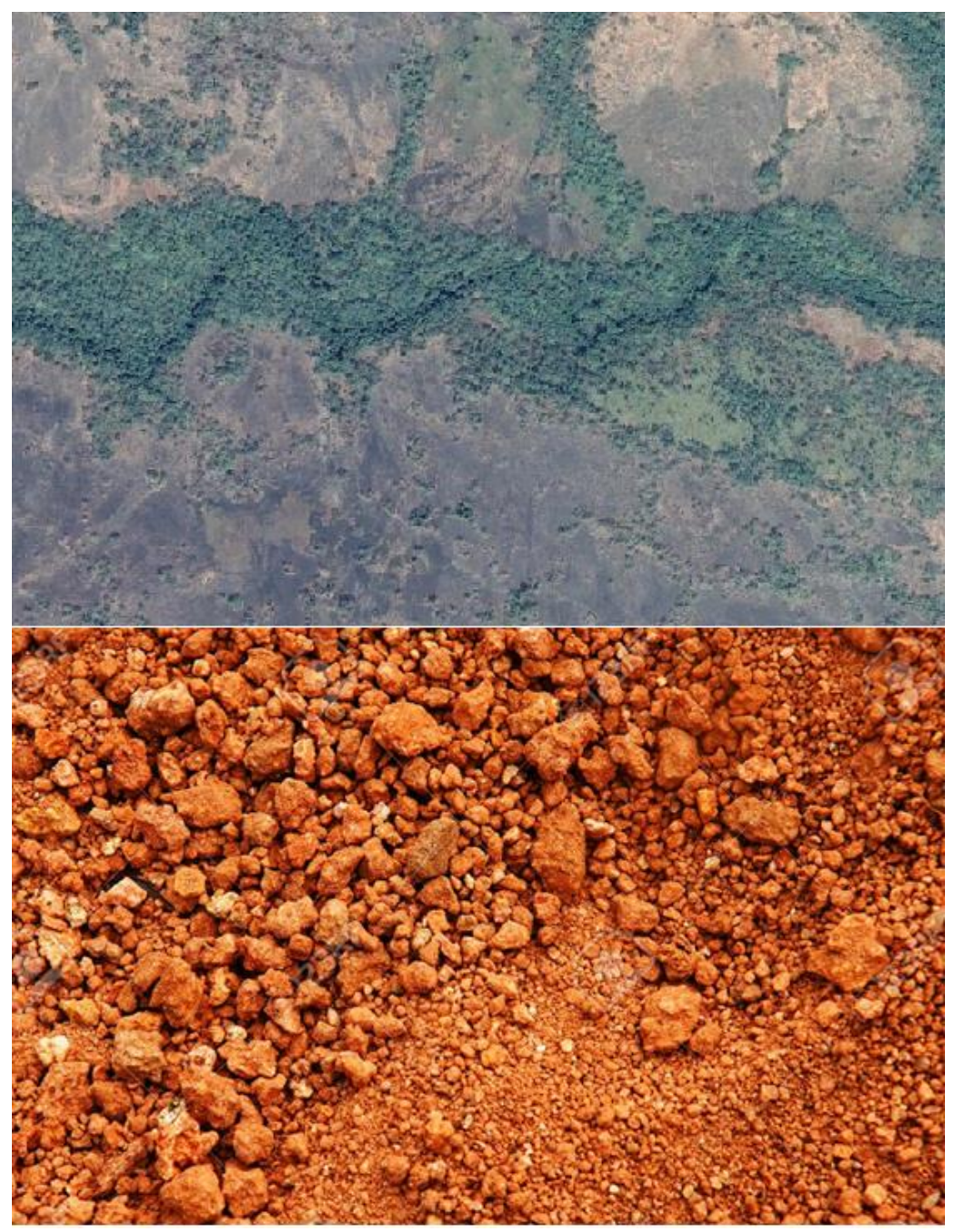

Figure 25. Nearly impermeable lateritic soils found Kedougou. These can be found extensively throughout Kedougou. 


\section{Recommendations and Future Work}

GSSHA can model single-storm events well. Although it is also capable of longterm simulations using multiple storm events, climactic data such as evapotranspiration rates, solar radiation, and humidity were unavailable for the study area. Future work may include simulating multiple rainfall events because of Senegal's convective storm systems that can unexpectedly influence discharge. During the calibration of the GSSHA model, NSE values were negative, as seen in Figure 14. Two rain events may have occurred, resulting in the two visible peaks found in the calibration run.

Precipitation was the most important and difficult aspect to incorporate into the model because of quality and availability. Additionally, rainfall distribution is both spatially and temporally sensitive. Applying a uniform spatial distribution for rain in a $\sim 2,500 \mathrm{~km}^{2}$ has limitations in Senegal. Convective storm systems (high intensity, short duration) are common in Kedougou. This causes rainfall to be localized in some areas, which may result in hydrological inaccuracies. The flooding observed using SAR seems to have been caused by upstream storms as precipitation measured by the Kedougou rain gauge was $0 \mathrm{~mm}$ two days before and including 08/18/18, according to Weather Underground (Weather Underground, 2019). The GSSHA model could be enhanced if Senegal and Guinea worked together to maintain a relatively dense network of stream gauges in the Gambia River watershed. The temporal distribution of rain also had limitations as storms do not always last 10 hours. Storms at the same intensity, but shorter time period may better display the runoff and streamflow impact of urbanization.

Limited data and time periods enhanced difficulty for model development and processes. Rainfall distribution over time was created utilizing satellite imagery from 2014, daily rainfall and discharge values for calibration and single storm simulation were obtained for an event in 2001. Land cover for 1992 and 2015 were chosen to obtain the largest difference between land cover transition. Although several difficulties and limitations occurred during the GSSHA modeling process, the model worked well enough to slightly overpredict flood extent. However, this is a result of the grid resolution versus SAR resolution. SAR-based imagery maintains a $20 \mathrm{~m}$ resolution, but the GSSHA model employed a $300 \mathrm{~m}$ resolution in which if flooding occurs in a small part of a grid cell, the entire grid cell will be flooded.

This research could be further improved if climate change were incorporated into single storm events. Scenarios could be developed combining precipitation rates, temperature increases, and vegetation data to predict vegetation reaction to specific climate changes. Additionally, this type of model could be used for urban planning, farmer assistance, and even health organizations. One of the biggest issues in Kedougou is malaria. Many non-governmental organizations work with the Kedougou community to lower the incidences of malaria related illnesses/deaths. Although computational time and demand would increase, a smaller grid size $(<50 \mathrm{~m})$, would provide highly specific data identifying more areas that flood as a result of the Gambia River, other streams in the river network, and direct precipitation.

The presented research is a solid foundation for applying GSSHA to data scarce regions. Much of the data obtained was globally available and easily accessed. My hope 
is that this research can provide the foundation to study ungauged, under resourced and unknown locations to better mitigate flood hazards and promote sustainability and resiliency. Also, the GSSHA model can be used in an interdisciplinary manner to assist different organizations and stakeholders. Through this integration of different disciplines, the most prevalent issues facing the community can be better handled and mitigated. 


\section{Conclusion}

Land cover between 1992 and 2015 in Kedougou did not change as expected. Initially, it was believed that shrubland would increase over time as global climate change has continually been exacerbated. However, compared to the drought of the 1980s, forest cover has increased. Between 1992 and 2015, forests increased by 6\%, whereas drought-resistant shrubland decreased by $4 \%$. Based on land cover imagery, all of KG-même was forested in 1992. In the 23 years between land cover scenarios, urban area increased from nonexistent to $2.75 \mathrm{~km}^{2}$. This change was significant enough to be detected by ESA satellite imagery.

GSSHA performed well for a hydrologic model considering limited data. The lower intensity flood event exhibited higher streamflow during the 1992 land cover scenario than 2015 and 2050. Much like the Sahel to the north, this "Sahelian paradox" was surprising. However, after analyzing and testing the data, it was apparent that pre-existing drought conditions influenced certain flora to die or thrive. The higher proportion of shrubland caused more surface runoff during the rain events.

Conversely, it is apparent that the IMERG-design storm hyetograph was a good solution to rainfall distribution over time. The validation process showed overlap between the simulated flooding results and observed SAR flood extent. A higher precipitation event was simulated to determine if flooding extent reached the downstream boundaries found in the SAR data. Through this process, it was determined that the 2015 land cover scenario simulated a larger Q than 1992. Rainfall amount was the only variable adjusted, but results were contrary to the first model run. However, projecting urban area increase between 2015 and 2050 did not have a significant effect on runoff or inundation for either storm event.

The GSSHA model performed accurately enough to determine how extreme precipitation events have affected and could affect Kedougou. Based on the $63 \mathrm{~mm}$ and $100 \mathrm{~mm}$ simulated storm events and 2050 land cover scenario, if urbanization in KG-même continues north or east of the town, it will not have a significant effect on discharge. However, if climate change affects flora in Guinea or more land use change occurs upstream (south) of KG-même, hydrologic analyses can be resumed with this model. 


\section{Bibliography}

Aduah, M.S., Warburton, M.L., Jewitt, G. (2015) Analysis of land cover changes in the Bonsa Catchment, Ankobra basin, Ghana. Appl. Ecol. Environ. Res. 2015, 13, 935-955.

Aduah, M.S., Graham, P.W., Toucher, M.L. (2017). Assessing Impacts of Land Use Changes on the Hydrology of a Lowland Rainforest Catchment in Ghana, West Africa. Water. 2017, 10.

ANSD (Agence Nationale de la Statistique et de la Demographie). (2019). Kedougou Regional Population Data. Available online at http://www.ansd.sn/index.php?option=com_regions\&view $=$ region\&id=9\&Itemid =1223. Accessed March 5, 2019.

Beye, A.S., \& Ndir, B. (2014). Service Régional de la Statistique et de la Démographie de Kédougou. 2014, Agence Nationale de la Statistique et de la Demographie (ANSD).

Bodian, A., Dezetter, A., Diop, L., Deme, A., Djaman, K., \& Diop, A. (2018) Future Climate Change Impacts on Streamflows of Two Main West Africa River Basins:

Senegal and Gambia. Hydrology. 5. 10.3390/hydrology5010021.

Brath, A., Montanari, A., Moretti, G. (2006). Assessing the effect on flood frequency of land use change via hydrological simulation (with uncertainty). Journal of Hydrology 324 (1-4), 141-153.

Central Intelligence Agency. (2019). Senegal. The World Factbook. Retrieved from https://www.cia.gov/library/publications/the-world- factbook/geo s/sg.html.

Chintalapudi, S., Sharif, H., Yeggina, S., El Hassan, A. (2012), Physically based hydrologic model results based on three precipitation products. JAWRA. 48, 6 .

Croke, Barry \& Merritt, Wendy \& Jakeman, A.J. (2004). A dynamic model for predicting hydrologic response to land cover changes in gauged and ungauged catchments. Journal of Hydrology. 291. 10.1016/j.jhydrol.2003.12.012.

Descroix, L., Mahé, G., Lebel, T., Favreau, G., Galle, S., Gautier, E., Olivry, J.-C., Albergel, J., Amogu, O., Cappelaere, B., Dessouassi, R., Diedhiou, A., Le Breton, E., Mamadou, I., and Sighomnou, D. (2009). Spatio-temporal variability of hydrological regimes around the boundaries between Sahelian and Sudanian areas of West Africa: A synthesis, J. Hydrol., 375, 90-102. 
Diop, N., Diop, O., Daffe, M. (2015). Etude hydrogéologique et hydrologique pour l'amélioration de l'alimentation en eau de la ville de Kédougou et de ses environnants, Rapport de le Direction de la Gestion et de la Planification des Ressources en Eau (DGPRE).

Downer, Charles \& Ogden, Fred. (2006). Gridded Surface Subsurface Hydrologic Analysis (GSSHA) User's Manual; Version 1.43 for Watershed Modeling System 6.1. 221.

Dwarakish G.S., Ganasri B.P. (2015). Impact of land use change on hydrological systems: a review of current modeling approaches. Cogent Geoscience $1: 1115691$. Encyclopedia Britannica Editors. (2012). "Fouta Djallon." Encyclopedia Britannica Online. Encyclopedia Britannica Inc., n.d. Available online at https://www.britannica.com/place/Fouta-Djallon. Accessed March 5, 2019.

El Hassan, A.A, H.O Sharif, T. Jackson, C. Singaiah. (2012). Performance of a conceptual and physically based model in simulating the response of a semiurbanized watershed in San Antonio, Texas. Hydrological Processes. 27, 24. 3394-3408.

ESA (European Space Agency). (2014). "Three global LC maps for the 2000, 2005, 2010 epochs." Available online at https://www.esa-landcover-cci.org/?q=node/158. Accessed March 15, 2019.

FAO (Food and Drug Administration) (2012). Identifying opportunities for climate-smart agriculture investments in Africa.

FAO (Food and Drug Administration (2010). Global Forest Resources Assessment 2010: Main Report; Food and Agriculture Organization of the United Nations: Rome, Italy, 2010; p. 378

Gal, Laetitia \& Manuela, Grippa \& Hiernaux, Pierre \& Pons, Léa \& Kergoat, Laurent. (2017). The paradoxical evolution of runoff in the pastoral Sahel: Analysis of the hydrological changes over the Agoufou watershed (Mali) using the KINEROS-2 model. Hydrology and Earth System Sciences. 21. 4591-4613. 10.5194/hess-214591-2017.

Hargreaves et al. (2019). "Senegal." Encyclopedia Britannica Online. Encyclopedia Britannica Inc., n.d. Available online at https://www.britannica.com/place/Senegal/Languages. Accessed March 5, 2019. 
Hänke, H., Börjeson, L., Hylander, K., \& Enfors-Kautsky, E. (2016). Drought tolerant species dominate as rainfall and tree cover returns in the West African Sahel. Land Use Policy, 59, 111-120.

Hulme, M., R. Doherty, T. Ngara, M. New, and D. Lister, (2001): African climate change: 1900-2100. Climatic Change, 17, 145-168.

Global Facility for Disaster Reduction and Recovery (GFDRR) (2012). Senegal: Disaster Risk Financing and Insurance Country Note. Available online at https://www.oxfamamerica.org/static/media/files/senegal-disaster-risk-financingand-insurance-country-note.pdf. Accessed March 20, 2019.

ISRIC (International Soil Reference and Information Centre). (2019). "SOTER Databases." Available online at https://www.isric.org/explore/soter. Accessed March 20, 2019.

Koranteng, Addo \& Zawila-Niedźwiecki, Tomasz \& Adu-Poku, Isaac. (2016). Remote Sensing Study of Land Use/Cover Change in West Africa. 2. 17-31.

Legesse Belachew, Dagnachew \& Vallet-coulomb, Christine \& Gasse, Françoise. (2003). Hydrological response of a catchment to climate and land use changes in Tropical Africa: case study South Central Ethiopia. Journal of Hydrology. 275. 67-85. 10.1016/S0022-1694(03)00019-2.

Ligtenberg, Jora. (2017). Runoff changes due to urbanization: A review. Retrieved from the DiVA portal

Moriasi, Daniel \& Arnold, Jeff \& Van Liew, Michael \& Bingner, Ron \& Harmel, R.D. \& Veith, Tamie. (2007). Model Evaluation Guidelines for Systematic Quantification of Accuracy in Watershed Simulations. Transactions of the ASABE. 50. $10.13031 / 2013.23153$.

NASA (National Aeronautics and Space Administration). (2019). "GPM Data Downloads." Available online at https://pmm.nasa.gov/dataaccess/downloads/gpm. Accessed March 15, 2019.

Nicholson, S. E., (1998). Historical fluctuations of Lake Victoria and other lakes in the Northern Rift Valley of East Africa. Environmental Change and Response in East African Lakes, J. T. Lehman, Ed., Kluwer, 7-35.

Nicholson, Sharon. (2005). On the Question of the "Recovery" of the Ravis in the West African Sahel. Journal of Arid Environments - J ARID ENVIRON. 63. 615-641. 10.1016/j.jaridenv.2005.03.004. 
Nka, N.B., Oudin, L., Karambiri, H., Paturel, J.E., Ribstein, P. (2015). Trends in floods in West Africa: Analysis based on 11 catchments in the region. Hydrology and Earth System Sciences. 19. 4707-4719. 10.5194/hess-19-4707-2015.

OECD (Organisation for Economic Co-operation and Development). (1991). Preparing for the future: A vision of West Africa in the year 2020. Available online at https://www.oecd.org/swac/publications/38512525.pdf. Accessed January 15, 2019.

Ogungbenro, Stephen \& Morakinyo, Tobi. (2014). Rainfall distribution and change detection across climatic zones in Nigeria. Weather and Climate Extremes. 5-6. 10.1016/j.wace.2014.10.002.

Ogden, Fred \& Y. Julien, Pierre. (1993). Runoff Sensitivity to Temporal and Spatial Rainfall Variability at Runoff Plane and Small Basin Scales. Water Resources Research - WATER RESOUR RES. 29. 2589-2597. 10.1029/93WR00924. Ogden, Fred \& Y. Julien, Pierre. (1993). Runoff Sensitivity to Temporal and Spatial Rainfall Variability at Runoff Plane and Small Basin Scales. Water Resources Research - Water Resources. 29. 2589-2597. 10.1029/93WR00924.

Pan, M., H. Li, and E. Wood. (2010). Assessing the Skill of Satellite-Based Precipitation Estimates in Hydrologic Applications. Water Resources Research 46:1-10

Paudel, Murari \& James Nelson, E \& Downer, Charles \& Hotchkiss, Rollin. (2011). Comparing the capability of distributed and lumped hydrologic models for analyzing the effects of land use change. Journal of Hydroinformatics. 13(3), 461.

Prause, Louise. (2016). West Africa's golden future? Conflicts around gold mining in Senegal. Rosa Luxemburg Stiftung. Accessed August 12, 2018.

Psomiadas, E. (2016). Flash Flood area mapping utilizing SENTINEL-1 radar data. Proceedings Volume 10005, Earth Resources and Environmental Remote Sensing/GIS Applications VII; 100051G (2016)

Rawat, J.S. \& Kumar, Manish. (2015). Monitoring land use/cover change using remote sensing and GIS techniques: A case study of Hawalbagh block, district Almora, Uttarakhand, India. The Egyptian Journal of Remote Sensing and Space Science. 1. 10.1016/j.ejrs.2015.02.002.

Rogger, Magdalena \& M, Agnoletti \& Alaoui, Abdallah \& Bathurst, J.C. \& Bodner, Gernot \& Borga, Marco \& Chaplot, Vincent \& Gallart, Francesc \& G, Glatzel \& Hall, Julia \& J, Holden \& Holko, Ladislav \& Horn, Rainer \& Kiss, Andrea \& Kohnová, Silvia \& Leitinger, Georg \& Lennartz, Bernd \& Parajka, Juraj \& 
Perdigao, Rui \& Blöschl, G. (2017). Land-use change impacts on floods at the catchment scale - Challenges and opportunities for future research. Water Resources Research. 53. 10.1002/2017WR020723.

Rouhana, Salim \& Ranarifidy, Dina. (2016). Cities for an emerging Senegal. World Bank Blog. Accessed March 20, 2019.

Savenije, Hubert. (1995). New definitions for moisture recycling and the relationship with land-use changes in the Sahel. Journal of Hydrology. 167. 57-78. 10.1016/0022-1694(94)02632-L.

Séguis, L., Cappelaere, B., Peugeot, C., and Vieux, B. (2002). Impact on Sahelian runoff of stochastic and elevation-induced spatial distributions of soil parameters, Hydrol. Process., 16, 313-332, https://doi.org/10.1002/hyp.337.

Séguis, L., Boulain, N., Cappelaere, B., Cohard, J. M., Favreau, G., Galle, S., Guyot, A., Hiernaux, P., Mougin, É., Peugeot, C., Ramier, D., Seghieri, J., Timouk, F., Demarez, V., Demarty, J., Descroix, L., Descloitres, M., Grippa, M., Guichard, F., Kamagaté, B., Kergoat, L., Lebel, T., Le Dantec, V., Le Lay, M., Massuel, S., and Trichon, V. (2011). Contrasted land-surface processes along the West African rainfall gradient, Atmos. Sci. Lett., 12, 31-37, https://doi.org/10.1002/asl.327.

Sith, R., Nadaoka, K. Comparison of SWAT and GSSHA for High Time Resolution Prediction of Stream Flow and Sediment Concentration in a Small Agricultural Watershed. Hydrology. 2017, 4, 27.

Tappan, G.G \& Sall, Moussa \& Wood, Eric \& Cushing, M. (2004). Ecoregions and land cover trends in Senegal. Journal of Arid Environments. 59. 427-462. 10.1016/j.jaridenv.2004.03.018.

Traore, Vieux \& Sambou, Soussou \& Talla Cisse, Mohamed \& Tamba, Séni \& Fall, Sidy \& Diaw, Amadou \& Sambou, Hyacinthe \& Edmond Nimy, Malanda \& Louis, Saint. (2014). Trends and shifts in time series of rainfall and runoff in the Gambia River Watershed. 2. 138-146. 10.11648/j.jepp.20140204.13.

USDA (United States Department of Agriculture). "Soil Water Characteristics." https://www.nrcs.usda.gov/wps/portal/nrcs/detailfull/national/water/manage/drai nage/?cid=stelprdb1045310. Accessed March 20, 2019.

USGS (United States Geological Survey). "Land use, land cover, and trends in Guinea." Available at https://eros.usgs.gov/westafrica/land-cover/land-use-land-cover-andtrends-guinea. Accessed on May 15, 2019. 
WeatherUnderground. Weather history for Kedougou, Senegal for August 27-28, 2019 (Weather Report). Retrieved from

https //www.wunderground.com/history/daily/sn/bandafassi/GAKY/date/2019-8$\underline{12 ? \mathrm{~cm} \_v e n=l o c a l w x \_h i s t o r y}$

Welde, Kidane \& Gebremariam, Bogale. (2017). Effect of Land Use Land Cover Dynamics on Hydrological Response of watershed: Case Study of Tekeze Dam Watershed, Northern Ethiopia. International Soil and Water Conservation Research. 5. 10.1016/j.iswcr.2017.03.002. 


\section{Appendix A. Processes and approximation techniques in GSSHA model}

\begin{tabular}{|l|l|}
\hline Process & Approximation \\
\hline \hline Precipitation distribution & $\begin{array}{l}\text { Thiessen polygons (nearest neighbor), } \\
\text { Inverse distance-squared weighting }\end{array}$ \\
\hline Snowfall accumulation and melting & Energy balance \\
\hline Precipitation interception & Empirical 2 parameter \\
\hline Overland water retention & Specified depth \\
\hline Infiltration & Green and Ampt (GA), \\
& $\begin{array}{l}\text { Multi-layered GA, } \\
\text { Green and Ampt with Redistribution (GAR), } \\
\text { Richard's equation (RE) }\end{array}$ \\
\hline Overland flow routing & 2-D diffusive wave \\
& - Explicit, \\
- Alternating Direction Explicit (ADE), \\
- ADE Predictor-Corrector (ADEPC)
\end{tabular}




\section{Appendix B. Overland Manning roughness coefficients (Downer and Ogden, 2006)}

\begin{tabular}{|c|c|c|}
\hline Land Use or Cover & Recommended n-value & Range \\
\hline Concrete or asphalt & $0.011^{\mathrm{a}}$ & $\begin{array}{l}0.01-0.013^{a} \\
0.05-0.15^{d}\end{array}$ \\
\hline Developed/industrial & $0.0137^{b}$ & - \\
\hline Bare sand & $0.01^{a}$ & $0.010-0.016^{a}$ \\
\hline Graveled surface & $0.02^{a}$ & $0.012-0.03^{a}$ \\
\hline Bare clay-loam (eroded) & $0.02^{a}$ & $0.012-0.033^{a}$ \\
\hline Gullied land & - & $0.320-0.357^{\circ}$ \\
\hline Bare field - no residue & $0.05^{a}$ & $0.006-0.16^{a}$ \\
\hline Range (natural) & $0.13^{a}$ & $0.01-0.32^{a}$ \\
\hline Range (clipped) & $0.10^{a}$ & $0.02-0.24^{a}$ \\
\hline Grass and pasture & - & $0.05-0.15^{a}$ \\
\hline Pasture & - & $\begin{array}{l}0.235-271^{c} \\
0.30-0.40^{d}\end{array}$ \\
\hline Clover & - & $0.08-0.25^{a}$ \\
\hline Small grain & - & $0.1-0.4^{a}$ \\
\hline Row crops & - & $0.07-0.2^{a}$ \\
\hline Cotton/soy & - & $0.246-0.261^{c}$ \\
\hline Grass (bluegrass sod) & $0.45^{a}$ & $\begin{array}{l}0.39-0.63^{a} \\
0.30-0.50^{d}\end{array}$ \\
\hline Short grass prairie & $0.15^{a}$ & $0.10-0.20^{\mathrm{a}, \mathrm{d}}$ \\
\hline Dense grass & $0.24^{a}$ & $0.17-0.30^{\circ}$ \\
\hline Bermuda grass & $0.41^{a}$ & $0.30-0.48^{a}$ \\
\hline Lawns & & $0.40-0.50^{d}$ \\
\hline Forest & $0.192^{\mathrm{b}}$ & $0.184-198^{c}$ \\
\hline Sparsely vegetated & $0.150^{\mathrm{b}}$ & $0.05-0.13^{d}$ \\
\hline Dense Growth & & $0.40-0.50^{d}$ \\
\hline
\end{tabular}




\section{Appendix C. Rawls and Brakensiek Soil Parameter Estimates (Downer and Ogden, 2006)}

\begin{tabular}{|c|c|c|c|c|c|c|c|c|}
\hline USDA Textural Classification & $\theta_{3}$ & $\theta_{0}$ & $\theta_{r}$ & $\theta_{\text {wp }}$ & $\psi_{b}(\mathrm{~cm})$ & $\lambda$ & $K_{0}\left(\mathrm{~cm} \mathrm{~h}^{-1}\right)$ & $\Psi_{f}(\mathrm{~cm})$ \\
\hline Sand & 0.437 & 0.417 & 0.020 & 0.033 & 7.26 & 0.694 & 23.56 & 4.95 \\
\hline Loamy sand & 0.437 & 0.401 & 0.035 & 0.055 & 8.69 & 0.553 & 5.98 & 6.13 \\
\hline Sandy loam & 0.453 & 0.412 & 0.041 & 0.095 & 14.66 & 0.378 & 2.18 & 11.01 \\
\hline Loam & 0.463 & 0.434 & 0.027 & 0.117 & 11.15 & 0.252 & 1.32 & 8.89 \\
\hline Silt loam & 0.501 & 0.486 & 0.015 & 0.133 & 20.79 & 0.234 & 0.68 & 16.68 \\
\hline Sandy clay loam & 0.398 & 0.330 & 0.068 & 0.148 & 28.08 & 0.319 & 0.30 & 21.85 \\
\hline Clay loam & 0.464 & 0.390 & 0.075 & 0.197 & 25.89 & 0.242 & 0.20 & 20.88 \\
\hline Silty clay loam & 0.471 & 0.432 & 0.040 & 0.208 & 32.56 & 0.177 & 0.20 & 27.30 \\
\hline Sandy clay & 0.430 & 0.321 & 0.109 & 0.239 & 29.17 & 0.223 & 0.12 & 23.90 \\
\hline Silty clay & 0.479 & 0.423 & 0.056 & 0.250 & 34.19 & 0.150 & 0.10 & 29.22 \\
\hline Clay & 0.475 & 0.385 & 0.090 & 0.272 & 37.30 & 0.165 & 0.06 & 31.63 \\
\hline
\end{tabular}




\section{Appendix D. Calibrated Land Cover and Soil Parameters}

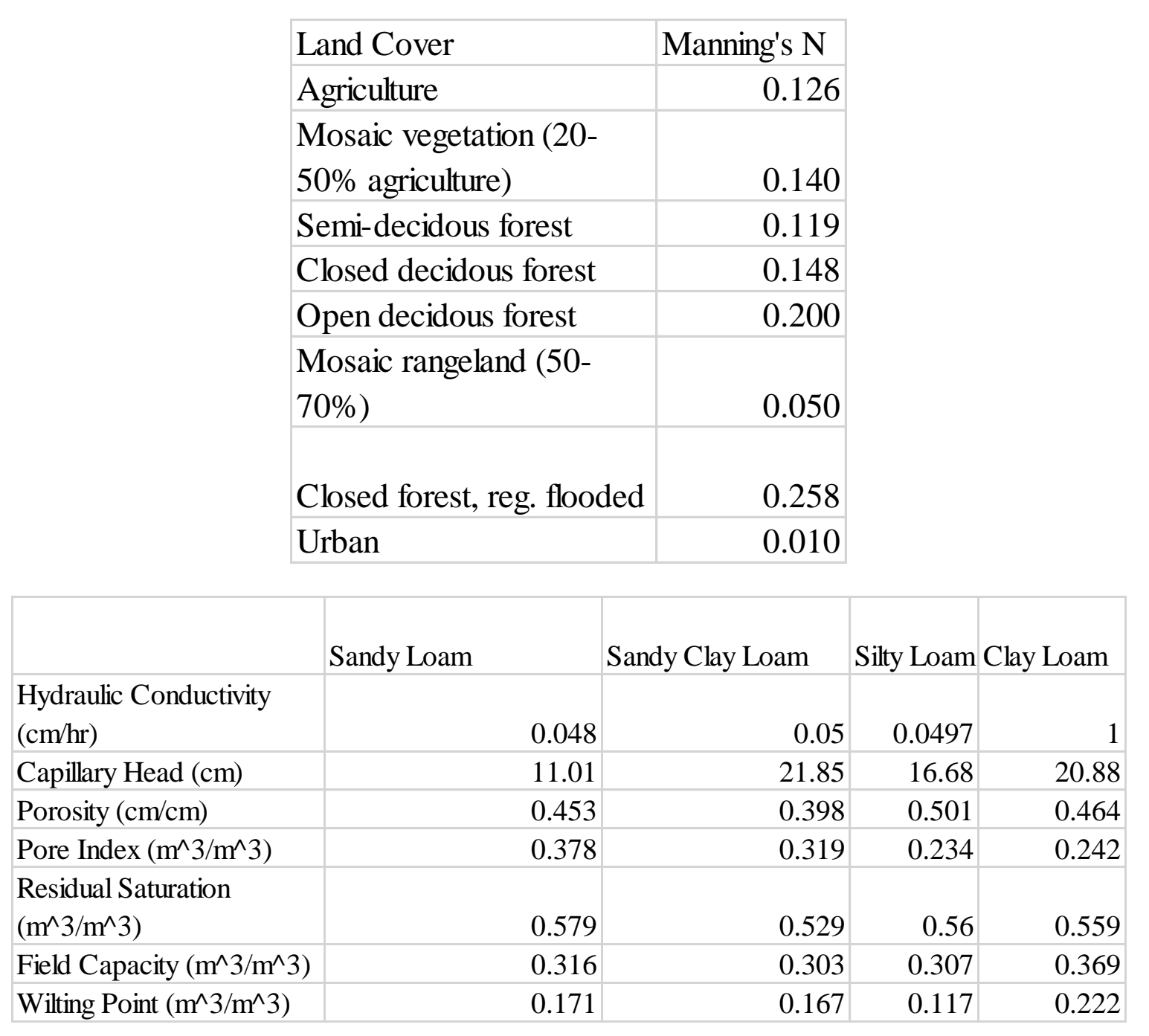

